\title{
The Evolution of National Retail Chains: How We Got Here*
}

by

\author{
Lucia Foster ${ }^{1}$ \\ U.S. Census Bureau
}

John Haltiwange $r^{1,2,3}$

University of Maryland

\author{
Shawn Klimek ${ }^{1}$ \\ U.S. Census Bureau \\ CJ Krizan ${ }^{1}$ \\ U.S. Census Bureau \\ Scott Ohlmacher ${ }^{1,2}$ \\ Unive rsity of Maryland
}

\section{CES 15-10 March, 2015}

The research program of the Center for Economic Studies (CES) produces a wide range of economic analyses to improve the statistical programs of the U.S. Census Bureau. Many of these analyses take the form of CES research papers. The papers have not undergone the review accorded Census Bureau publications and no endorsement should be inferred. Any opinions and conclusions expressed herein are those of the author(s) and do not necessarily represent the views of the U.S. Census Bureau. All results have been reviewed to ensure that no confidential information is disclosed. Republication in whole or part must be cleared with the authors.

To obtain information about the series, see www.census.gov/ces or contact Fariha Kamal, Editor, Discussion Papers, U.S. Census Bureau, Center for Economic Studies 2K132B, 4600 Silver Hill Road, Washington, DC 20233, CES.Papers.List@census.gov. 


\begin{abstract}
The growth and dominance of large, national chains is a ubiquitous feature of the US retail sector. The recent literature has documented the rise of these chains and the contribution of this structural change to productivity growth in the retail trade sector. Recent studies have also shown that the establishments of large, national chains are both more productive and more stable than the establishments of single-unit firms they are displacing. We build on this literature by following the paths of retail firms and establishments from 1977 to 2007 using establishmentand firm-level data from the Census of Retail Trade and the Longitudinal Business Database. We dissect the shift towards large, national chains on several margins. We explore the differences in entry and exit as well as job creation and destruction patterns at the establishment and firm level. We find that over this period there are consistently high rates of entry and job creation by the establishments of single-unit firms and large, national firms, but net growth is much higher for the large, national firms. Underlying this difference is far lower exit and job destruction rates of establishments from national chains. Thus, the story of the increased dominance of national chains is not so much due to a declining entry rate of new single-unit firms but rather the much greater stability of the new establishments belonging to national chains relative to their singleunit counterparts. Given the increasing dominant role of these chains, we dissect the paths to success of national chains, including an analysis of four key industries in retail trade. We find dramatically different patterns across industries. In General Merchandise, the rise in national chains is dominated by slow but gradual growth of firms into national chain status. In contrast, in Apparel, which has become much more dominated by national chains in recent years, firms that quickly became national chains play a much greater role.
\end{abstract}

\footnotetext{
* Any opinions and conclusions expressed herein are those of the authors and do not necessarily represent theviews of the US Census Bureau. All results havebeen reviewed to ensure that no confidential information is disclosed. We thank Ron Jarmin for helpful comments. Wethank Teresa Fort for sharing the time-consistent NAICS codes with us. This is an updated version of a paper last circulated in 2007. Affiliations:

${ }^{1}$ Census Bureau

${ }^{2}$ University of Maryland

${ }^{3} \mathrm{NBER}$
} 


\section{Introduction}

A dominant feature of the US retail industry is the growth and prevalence of large, national chains in the retail industry. The best-known example is Walmart, but large, national chains in many different retail sectors have become paramount. Examples such as Starbucks, Whole Foods, and H\&M come to mind when thinking of national chains that have succeeded dramatically over the last few decades. The increasing preeminence of national chains and their impact on the size distribution and firm turnover rates in retail trade is documented by Jarmin, Klimek, and Miranda (2009). Foster, Haltiwanger, and Krizan (2006) find that virtually all of the productivity growth in the US retail trade market over the 1990s is due to more productive entering establishments affiliated with national chains displacing much less productive exiting single-unit firms. Some research has started to address the factors that prompted these dynamics. For example, Holmes (2011) explores some of the tradeoffs affecting Walmart as it opens new establishments in the US and how these factors influenced the overall location pattern followed by the firm.

We build on this literature by describing the evolution of chain types in retail trade from 1977 to 2007 using establishment- and firm-level data from the Census of Retail Trade and the Longitudinal Business Database. We begin by exploring the paths followed by firms of different chain types - comparing for example the dynamics of single-establishment firms to those we designate as National firms (firms that operate in at least 18 states). We find that National firms increasingly dominate the retail trade sector and exhibit different patterns of volatility as measured by job creation and destruction as well as entry and exit. Given their increasingly dominant role, we then focus our attention on the National firms to understand the patterns of expansion for such firms. We are interested in understanding different paths to 
achieving National chain status. Some firms gradually expand over geography, eventually becoming a national presence over time, while others seem to establish a national foothold relatively quickly. Part of our analysis focuses on four industries for in-depth study to help us understand different paths leading to the rise of National chains.

The paper proceeds as follows. Section 2 provides a brief literature review to help put the questions and approach of the paper into context. Section 3 describes the data used in the analysis. Section 4 presents an overview of the patterns of structural change in the retail trade sector. Section 5 provides an analysis of the patterns of job creation and destruction and entry and exit at both the establishment and firm level across chain types. Section 6 explores the evolution of the large, national firms that became paramount in the retail trade sector by 2007 . In Section 7 we examine the evolutionary paths of four industries in retail trade. Concluding remarks are given in Section 8.

\section{Literature Review}

The dramatic changes in the retail trade sector have yielded a burgeoning literature documenting and exploring the factors underlying the transformation. Jarmin et al. (2004, 2009) document and analyze the patterns of growth and change in the retail trade sector using the Longitudinal Business Database (LBD). They find an increasingly dominant role of large, national chains in retail trade activity as measured by payroll and employment. Moreover, they quantify the extent and patterns of firm and establishment entry and exit in the retail trade sector. Not surprisingly, entry and exit rates are relatively high in retail trade (e.g., compared to manufacturing) but they also find that entering establishments are much larger in terms of relative size to incumbents as compared to their manufacturing counterparts. They also show 
that the patterns of activity and change vary across market size and type. Rural areas are still served by a relatively large number of single-unit establishment firms but in rural areas such firms are experiencing net losses. In larger markets, there is higher firm turnover. They also find that single-unit firms and large, national chains are more likely to coexist in some industries (such as Restaurants) and less likely in others (such as General Merchandise stores).

Basker, Klimek, and Van (2012) focus on the rise of big-box stores in the General Merchandise sector. They note that changes in customer preferences and technology have led to General Merchandise stores dominating specialist retail chains. In terms of consumer preferences they note, "Until the late 1970s, more than half of all of the consumer dollars were spent at single-store retailers; today more than $60 \%$ of consumer dollars are spent at a chain store, double the share of 1954” (p.545). Using micro-level data from the Census of Retail Trade for 1977-2007, they find that large chain General Merchandise stores expanded over two complementary dimensions: number of stores and number of product lines.

One outstanding example of the dramatic changes among retail trade firms is Walmart. Not surprisingly, some of the literature documenting and studying the evolving structure of the sector focuses on Walmart. Basker (2005) finds that although there is an initial increase in employment in the local area, over the subsequent five years a Walmart entry yields exits and contractions by competitors. She also finds evidence for upstream effects via a decline in wholesalers' employment. Basker et al. (2012) quantify this impact, estimating that Walmart's expansion of 3,000 locations caused the closure of 12,000 competing stores. Haltiwanger, Jarmin, and Klimek (2010) find that the displacement effect of big box store entry especially impacts businesses located in close physical proximity to the big box store. Holmes (2011) also explores Walmart entry dynamics by documenting its geographic pattern of expansion. Walmart started in Bentonville, Arkansas, and first expanded into local, then regional, and then finally 
national markets. Holmes models the firm's expansion decision as a tradeoff between taking advantage of the economies of density (favors operations in close proximity) versus locating in the market with the highest quality (unlikely to favor operations in close proximity). In contrast, according to the National Retail Federation, H\&M became a bicoastal presence within five years of its first opening in the US and achieved a national presence within 14 years. ${ }^{1}$

These dramatic changes in the structure of the retail trade sector have been associated with concurrent productivity growth in retail trade. Foster et al. (2006) show that virtually all of the labor productivity growth in the US retail trade sector over the 1990s is accounted for by more productive entering establishments displacing much less productive exiting establishments. Interestingly, the large productivity gap between low productivity exiting singleunit establishments and entering high productivity establishments from large, national chains plays a disproportionate role in these dynamics.

While much has been learned from this growing literature, our understanding of the structural changes in the retail trade sector is still limited. The development of the LBD (see Jarmin and Miranda, 2002) provides a rich new resource for the study of these issues (as in Jarmin et al. (2004, 2009)) and also provides longitudinal establishment and firm identifiers to conduct analysis of firms over an extended period of time (1977 to the present). The current paper takes advantage of the integration of the LBD with the Census of Retail Trade (CRT) from 1977 to 2007 to expand our understanding of the major structural changes ongoing in the retail trade sector. $^{2}$

\footnotetext{
${ }^{1}$ Schulz(2014) from National Retail Federations roundup of Top 100 Retailers: "H\&M opened its first US store in New York in 2000, hit the West Coast five years later and now has roughly 300 stateside stores...”

${ }^{2}$ The development of the LBD permits the longitudinal analysis of the CRT from 1977-2007. Foster et al. (2006) only used the CRT for 1987-97 given that the LBD had not been developed when the analysis was conducted.
} 


\section{Data and Measurement Issues}

The empirical analysis in this paper uses data from the CRT. The Census Bureau conducts a survey of retail trade establishments every five years (those years ending in '2' and '7’). The survey questionnaire is mailed out to all large and medium-sized firms and generally all firms that operate multiple establishments; most very small firms are excused from answering the questionnaire. The data for these very small firms come from either a Census sample of these very small firms or administrative records from other federal agencies. We use both reported data and administrative data in our empirical exercises because there is no reason to suppose that the administrative records data are inferior to the reported data for the variables used in this study.

The CRT contains high-quality data on establishments for the period 1977-2007 concerning the kind of business, physical location, sales in dollars, annual and first quarter payroll, and employment for the pay period including March $12^{\text {th }}$. The data also include information that enables us to connect establishments to the firms that own them. We create a measure of real sales (in 2007 dollars) by deflating nominal sales by the Consumer Price Index in each year.

During the sample period, the industry classification system used by Census in collecting data switched from the Standard Industrial Classification (SIC) to North American Industry Classification System (NAICS). In order to ensure comparability across time, we define the retail trade sector using the SIC definition for our entire sample period. Fortunately, the Census Bureau maintained SIC industry information in the NAICS transition year (1997) so creating the 1997 retail trade sector under SIC is straightforward. We create a version of 2002 retail trade sector under SIC by applying 1997 SIC codes to continuing establishments in 2002 and using a 
SIC-NAICS concordance to translate the industry codes for establishment births in 2002 (see the Data Appendix for more details). We then extend this methodology to generate the 2007 retail trade sector under SIC by applying these 2002 SIC codes to continuing establishments in 2007 and using the concordance to identify establishment births in SIC industries in 2007. To the extent that we cannot remove all establishments that first appear in the 2002 and 2007 CRTs and are in NAICS-only industries, our sample slightly overestimates the 2002 and 2007 retail trade sectors on an SIC-consistent basis.

Since we will be using LBD data in our analysis, we restrict our sample to establishments with positive employment, sales and payroll that can be matched to the LBD. This restriction on positive employment helps us increase the quality of our data in early Census years. Our sample exhibits quantitatively similar time series patterns as the published data of the full universe of the retail trade sector.

We define the retail trade sector on an SIC basis when generating the sample, but use Fort-Klimek time-consistent NAICS (FK-NAICS) industries linked to the LBD for all industrylevel analysis to ensure consistency in our results. The FK-NAICS codes are assigned at the establishment level; a multi-industry firm is assigned the industry that accounts for the largest share of the firm's payroll. While using FK-NAICS ensures that continuing establishments are matched to the same industry over the entire sample, a firm could change industries across observations due to a change in the composition of its overall payroll.

Our measure of productivity is labor productivity defined as the log of total sales over total employment. All measures of productivity are industry-demeaned at the 6-digit NAICS level using FK-NAICS codes. Establishment-level productivity calculates productivity of the establishment, demeaned at the establishment’s 6-digit NAICS industry. Firm-level productivity is log firm-level sales over firm-level employment, demeaned at the firm's 6-digit NAICS 
industry.

We define chains in terms of the number of establishments in operation and the number of states in which these establishments operate. We classify firms into five chain types: Single (firms with a single establishment), Local (firms with multiple establishments all operating in the same state), Divisional (firms with multiple establishments operating over two to five states), Regional (firms with multiple establishments operating over six to 17 states), and National (firms with multiple establishments operating over 18 or more states). ${ }^{3}$ As will become clear, the chain size categories are quite instructive for characterizing the changing structure of the US retail trade industry. Firms may move between chain types over time as they expand or contract.

One shortcoming of our analysis is an inability to account for franchises. Many of the firms that spring to the mind of the reader when considering "National chains" may be franchises rather than chain stores. For the purpose of our sample, franchised establishments are considered independent of other establishments under the same brand unless they are owned by the same legal entity. Thus, many franchises are Single, Local, or Divisional chains in our analysis. Since we do not include many franchises in our characterization of large, national chains, our findings on the dominant role of the latter are likely understated.

Since we aggregate to the firm-level from establishment-level data, it is important to note that we are measuring retail activity by firms, not all activity by firms with retail presence. If a chain operates in retail and non-retail spaces, our sample only includes activity at the retail

\footnotetext{
${ }^{3}$ This precise cutoff is somewhat arbitrary but we have found our results are robust to alternative similar cutoffs. We used this cutoff since firms that operate in at least 18 states must be operating in more than oneCensus region. Note that firms achieve "National" status by virtue of the number of states they operate in so this is similar to, but more restrictive than, the definition of "National" chain used in Foster et al. (2006) which was a multiunit firm that operates in 5 or more states. Note that it is not defined based on thenumber of stores that a firm operates nor the size of the individual stores. Thus this definition overlaps imperfectly with the definition of "Large" chain used in Basker et al. (2012) (a firm with 100 or more establishments), and theconcept of a "Big Box" store used in Haltiwanger, Jarmin, and Krizan (2010).
} 
establishments. For example, if a wholesale chain has exactly one retail establishment, that establishment is considered a Single firm in our analysis, and we would measure only economic activity at the retail establishment.

Finally, the micro data are subject to strict disclosure avoidance reviews to ensure the confidentiality of respondents. All analyses using Census Bureau micro-level data must not reveal the identity of any of the firms that we are studying. Any discussion of firms by name in this paper comes from public sources and does not imply that the firm is part of the micro-data. These discussions are intended solely to provide context for the empirical exercises.

\section{Trends in Retail Trade}

The number of firms and establishments, employment and real sales in our sample from 1977 to 2007 are shown in Figure 1. The number of firms is large (about one million) and relatively constant over this period. The number of establishments, not surprisingly, is much larger and the gap between the number of firms and establishments has risen steadily. The number of retail establishment grows from 1.3 million in 1977 to 1.5 million in 2007. Employment and real sales are also very large, with the retail trade sector accounting for about 25 million workers and over \$4 trillion in gross real sales (2007 dollars) in 2007. Employment and sales both grew rapidly over the period.

We decompose measures of economic activity by firm and chain type in Figure 2. We show employment (top-left panel) and real sales (lower-left panel) for single-unit firms and multiple-establishment firms for the retail trade sector from 1977 to 2007. In 1977, employment and sales for single-unit firms and multiunit firms were about the same, but since then employment and sales increased more rapidly for multiunit firms than for single-unit firms. By 
2007, multiunit firms account for roughly two-thirds of sales and employment in the retail trade sector.

On the right-hand side of Figure 2, we show employment (top-right panel) and real sales (lower-right panel) by chain type. The figure shows dramatic growth in employment and sales for National retail firms from 1977 to 2007. Clearly, the growth in multiunit firms' sales and employment is dominated by the growth in sales and employment for National firms. The other chain types have more modest growth in employment and sales. The employment shares by chain type show a dramatic increase for National firms (from 20\% to 34\%) at the expense of Single firms (from 49\% to 37\%), with little change for the other chain types. Table 1 provides summary statistics on chain types for 1977 and 2007 and confirms the growing dominance of National firms. The number of National firms more than doubles, and the total number of establishments associated with National firms also more than doubles over the period (Panel A, Table 1). In contrast, the number of firms and the number of establishments associated with Single and Local firms does not change much over the period.

Jarmin et al. (2004, 2009) point out that the share of activity in retail trade accounted for by large, national chains has been growing over the entire post-WWII period. There is acceleration in the growth, particularly for real sales, among the National firms during the last two-thirds of the period 1977-2007. According to Figure 2, the compound annual growth rate in real sales for National firms is $4 \%$. The compound annual growth rate of real sales for National firms is $2.6 \%$ for the period $1977-87$ and $4.7 \%$ for the period $1987-2007$.

We provide information about firm differences across the chain types in Panel B of Table 1. Not surprisingly, the average number of establishments per firm is much larger for National firms than for other firms. The average number of establishments in 2007 for Local firms is three, 12 for Divisional firms, 85 for Regional, and 651 for National firms. Interestingly, 
the average number of establishments per firm grew over the sample only for Divisional and National firms; it stayed flat or fell for Local and Regional firms and is constrained to be one for Single firms.

Turning to employment, the next rows show that the firm size rises over chain types such that average employment rises by about a factor of about eight over chain types (except for Local to Divisional which rises by about half that). The average National firm is over 2,000 times the size of the average Single firm in terms of employment and sales. Over our period of observation, there is modest growth in average employment and average real sales for all chain types. Local firms have the largest increase in scale over the period. ${ }^{4}$ Returning to Figures 1 and 2, it is clear that the rapid increase in sales and employment in the retail trade sector is due to the size and especially the number of National firms.

The last rows in Panel B show the average size of firms weighted by employment. This statistic provides a summary measure of the coworker mean, which is the size of the average firm for the average worker (see Davis, Haltiwanger, and Schuh (1996)). In 2007, the average employee in a Single firm has 38 coworkers while the average employee in a National firm has 240,422 coworkers. Comparing the coworker mean to the simple mean for National firms (204,422 versus 19,060), we see that while National firms are large on average, their size distribution is highly skewed so that the average worker at a National firm works for a very large firm.

We present statistics on the intensity of activity within the different chain types in Panel C. One possibility is that the dramatic increase in National firms simply represents a shift in the

\footnotetext{
${ }^{4}$ The percentage change in the average sales per firm by chain typeover $1977-2007$ is: $20 \%$ Singles, 58\% Local, $41 \%$ Divisional, $24 \%$ Regional, and $48 \%$ National. The pattern for average employment per firm by chain type is similar.
} 
distribution of firms over the number of establishments. As firms grow, they mechanically move from one category to the next larger category. Thus, we would expect to see that Regional and National firms are very similar except for the number of states in which they operate. A Regional firm establishes its presence in its covered states and then has a similar presence in new states as it becomes National. However, the average number of establishments per state differs dramatically over the chain types, suggesting that there is another dynamic at work. For example, in 2007 intensity increases monotonically from three for Local firms (recall Single must be one), five for Divisional, nine for Regional, to 17 for National. Interestingly, this difference in intensity seems to be relatively stable over time.

While we have tried to define our chain types in a meaningful way, our definition of National chains potentially covers a wide variation in the number of states. The average number of states covered by National firms has grown over time: while only $8 \%$ of National chains operated in 46 states or more in 1977 this rose to $19 \%$ in 2007. Figure 3 compares the share of economic activity (employment and revenue) of National chains in 1977 and 2007 over four broad classes of state coverage (18-25, 26-35, 36-45, 46+). Although the four classes of state coverage are chosen so that roughly 25\% of all 2007 National firms are in each class, the firms with the widest coverage account for nearly 60\% of total 2007 National chain employment and revenue, up from about $40 \%$ in 1977. In other words, the rising domination of National chains is due to both their geographic coverage getting wider as well the higher intensity with which they operate within states.

The analysis in this section establishes the increasingly dominant role of National firms in retail trade. In the next section, we provide a richer picture of the restructuring in the retail trade sector by examining the patterns of job creation and destruction and entry and exit across chain types. This analysis will then lead us to an exploration of the nature of the dramatic 
increase in the role of National firms.

\section{Restructuring of Retail Trade}

The analysis in the prior section provides evidence of the restructuring between chain types over the last few decades in the retail trade sector. To look deeper into this restructuring, we calculate job creation and destruction as well as entry and exit rates so we can examine the pace and nature of the restructuring within chain types. We follow the methods developed and described in Davis et al. (1996) and used for the retail trade analysis in Foster et al. (2006). When calculating and constructing these measures, we do so at both the establishment and the firm levels.

For job creation by establishments, we measure the employment gains by all expanding and entering establishments from one observation to the next. Entry reflects the true births of establishments in the sense that there is a new establishment at a physical location in the year in question. For job destruction, we measure the employment losses by contracting and exiting establishments. Exit reflects the true death of establishments in the sense that the establishment at a given physical location ceases operations at that location. We convert the flows to rates by dividing the flows by average employment. By construction, all job flow measures are employment-weighted growth rates. We report the entry and exit rates on both unweighted and employment-weighted bases. All job flow and entry and exit rates are over five-year horizons. As in the prior section, we assign establishments to chain types based upon the characteristics of the parent firm. ${ }^{5}$

\footnotetext{
${ }^{5}$ For establishments at new and continuing firms and establishments that continue beyond the death of the period ( $t$ 5) parent firm, theseare the characteristics of the parent firm in year $t$ where job flows and entry and exit rates are
} 
At the firm level, job creation and destruction numbers reflect analogous concepts. Consistent with Haltiwanger, Jarmin, and Miranda (2013), entering firms are defined as new firms with all new establishments, while exiting firms are firms that exit along with all of their establishments. Job creation at the firm level is net creation at continuing establishments and new establishments associated with the firm at the end of the period. Firm-level job destruction is defined as destruction at continuing establishments associated with the parent firm at the end of the period and exiting establishments that were associated with the parent firm at the start of the period. By building up firm-level creation and destruction from establishment-level creation and destruction, our firm-level measures only capture organic growth and decline.

We show the patterns of job creation and destruction where the unit of observation is the establishment in Figure 4. The top panel shows a high pace of job creation for all chain types with the highest pace for Single establishments. Over a five-year horizon, job creation for Single establishments is about 55\% of employment, but even establishments associated with National firms have a high pace of establishment-level job creation (around $45 \%$ of employment). For establishments of Single firms, the pace of job destruction is also very high - around 50\% of employment (bottom panel of Figure 4). However, job destruction for establishments from National firms over a five-year horizon is substantially lower at around $30 \%$ of employment. Thus, the difference in the net growth of Single firms and National firms is primarily associated with much lower job destruction rates for establishments from National firms.

With the exception of Regional firms, job destruction at establishments is monotonically decreasing in chain size, with roughly uniform patterns over the sample period. Job destruction at Regional firms fluctuates nearly 20 percentage points between 1977 and 2007, at one point firm in period $(t-5)$. 
having the lowest rate of establishment-level job destruction, and later exhibiting the secondhighest rate of job destruction of all chain sizes. The root cause of this dramatically different pattern of job destruction at Regional firms remains an open question. It may be because some regional firms are on the way up while others are on the way down. We discuss the role of Regional firms as a transitional chain size in Section 6.

When utilizing the firm as the unit of observation (shown in Figure 5), the patterns of job creation and destruction across chain types yield more differences. By construction, creation and destruction patterns for Single firms are similar to that of Single establishments. ${ }^{6}$ Job creation for Single firms at the firm level averages about 60 percent and job destruction at the firm level averages about 50 percent. However, for chain firms and especially National firms, both job creation and especially job destruction are much lower at the firm level. For National firms, job creation at the firm level averages just over 25 percent of employment while job destruction averages less than 10 percent of employment.

Comparing Figure 4 and Figure 5 reveals that job creation for National firms is about 18 percentage points below the job creation by establishments for National firms and job destruction for National firms is 19 percentage points below the job destruction by establishments for National firms. Coupled with the similar gap between job creation for National firms and job creation for National establishments, this implies that that National firms exhibit considerable within-firm reallocation. The gap between the firm level and establishment

\footnotetext{
${ }^{6}$ The job creation and destruction and entry and exit statistics for single-units are not identical at the establis hment and the firm level given the difference in the nature of identifiers used at the establishment and firm levels of analys is. When we compute es tablis hment-level flows, we use an es tablishment-level identifier that is invariant to owners hip change - and as noted in the text, entry is true entry and exit is true exit. When we compute firm-level statis tics we use a firm-level identifier that changes when thelegal entity owning the firm changes. In Tables 2 and 3 , the statistics at the firmand establishment-level are very similar but establishment-level flows differ slightly due to ownership changes and the possibility that a single unit firm replaces its single establishment between observations.
} 
job flows captures this within-firm reallocation. Within National firms, there are simultaneously some establishments shrinking while other establishments expand.

We provide summary statistics about patterns of entry and exit, respectively, across chain types in Tables 2 and 3. Two closely related but distinctly different sets of statistics are reported. In Panel A, we report the shares of creation (destruction) accounted for by entry (exit) at both the establishment and firm-level. The denominator is total job creation (destruction) by chain type, so a high share tells us about the importance of the entry (exit) margin for creation (destruction). ${ }^{7}$ In Panel B, we report entry (exit) rates at both the establishment and firm levels on unweighted and employment-weighted bases. The unweighted entry (exit) rate denominator is the average number of firms or establishments for the chain type in question. The denominator of the employment-weighted entry (exit) rate is average employment for the chain type.

For all types of firms, about 75\% of establishment-level job creation over a five-year horizon is from establishment entry (Panel A, Table 2), with very little variation across chain sizes. It is striking that this pattern holds for all chain sizes so that job creation at the establishment level is dominated by establishment entry even for National firms. This implies that retail expansion is not driven by expanding the size of existing stores as much as it is by opening new locations.

The five-year entry rate of establishments is higher for Single firms than for

\footnotetext{
${ }^{7}$ We report two different levels of analysis of the share of creation/destruction dueto firm entry/exit. The analysis that follows focusses on the share of firm-level creation/destruction due to firmentry/exit, which uses net creation/destruction at the firm level as the denominator. We als o report the share of establishment-level creation/destruction due to firm entry/exit, which allows for both creation and destruction occurring simultaneously at different establishments within the same chain. Firm-level job destruction due to firm exit is much higher than the share of es tablishment-level destruction due to firm exit at National firms. Thus, there is considerable job destruction even within National firms that are net job creators. The difference is much less stark on the creation margin, indicating that National firms that are net job destroyers are much less likely to be creating jobs at some establishments.
} 
establishments owned by National firms. Similarly, the five-year entry rate of firms is higher for Single firms than for National firms. However, the gap in the latter is much larger than the former. While there is relatively little entry of new National firms, there is robust entry of new establishments at National firms. Panel B also shows that there has been a substantial decline in the employment-weighted firm-level entry rate for Single, Local, Divisional and Regional firms over time. This decline in employment-weighted firm-level entry rates is consistent with the findings in Davis, Haltiwanger, Jarmin and Miranda. (2007) and Decker, Haltiwanger, Jarmin and Miranda (2014a,b) and is one of the factors underlying the decline in business dynamism in the U.S.

Turning to the share of job creation by entering firms, the pattern for Single firms is about the same as at the establishment level and is high - around $80 \%$. In contrast, for National firms only a very small share of the job creation at the firm level is due to firm entry. The low share for National firms combined with the lower firm-level creation rate in Figure 4 implies a low entry rate for National firms; it is below $1 \%$ on an employment-weighted basis over the sample over a five-year horizon (Panel B), which is not surprising since even over a five-year horizon few firms are born as National firms.

Turning again to the destruction side in Table 3, for Single establishments, exits dominate job destruction accounting for nearly $80 \%$ of job destruction over a five-year horizon. Put simply, if a Single establishment contracts, it often contracts via exit. In contrast, the share of job destruction from establishment exit by the establishments of National firms is substantially lower. In the 1997 to 2007 period, about 56\% of the job destruction at the establishment level for National firms is via establishment exit.

In terms of job destruction by exiting firms, we see very different patterns across chain types as well. National firms have a much lower share of job destruction from firm exit than 
Single firms. As we saw in Figure 5, the job destruction rate for National firms is low. The fiveyear employment weighted rate exit rate at the firm level is around $2.8 \%$ of employment, while the unweighted exit rate is about $17.6 \%$ of all National firms. Thus, the average exiting National firm is smaller than the continuing National firms.

The average size of establishments varies across chain types including the size of the typical entrant across chain types. For example, in 2007 the average single unit incumbent establishment had 11 employees, the average single unit entrant had 8 employees, the average incumbent establishment belonging to a National firm had 32 employees and the average entering establishment belonging to a National firm had 24 employees.

Putting the pieces together, National firms are much more stable than their Single counterparts in terms of job destruction (both firm- and establishment-level). Once created, an establishment from a National firm as well as the overall National firm is much less likely to contract and exit than a Single firm. Thus, in an accounting sense, the rise of the National firms is not so much because of the lack of job creation and entry by Single firms (although this has fallen over time) but rather the almost as high job creation and establishment entry for National firms and the very low job destruction and establishment and firm level exit of National firms. ${ }^{8}$

In terms of overall establishment and firm volatility, the increasing role of National firms is clearly a factor contributing to the decline in firm and establishment volatility documented by Davis et al. (2007) and Decker et al. (2014a,b). One measure of overall establishment or firm volatility is job reallocation (the sum of creation and destruction at the establishment or firm level). The substantially lower job destruction rates for establishments from National firms, the

\footnotetext{
${ }^{8}$ This also begs the question: "How is it that National firms have such high rates of job creation from establishment-level entry?” A common finding on job flows is that small establishments and firms have high job creation and destruction rates. This pattern holds in retail trade for Single units. However, Nationals have a high rate of establishment entry and very low rate of establishment exit.
} 
associated lower job destruction rates at the firm level for National firms, and the shift in employment shares towards National firms implies establishment and firm volatility has been declining in retail trade. While Davis et al. (2007) and Decker et al. (2014a,b) suggest a variety of hypotheses for the economy-wide decline in firm and establishment volatility, the restructuring of the retail trade sector is clearly an important factor, and it is of interest to explore the role of large, national chains for the declining volatility in other sectors.

\section{The Rise of National Firms in Retail Trade}

The previous sections illuminated the increasing dominance of National firms in retail trade; we now turn to examining the path and the factors that led to this phenomenon. We found the increase in economic activity associated with National firms reflects both more and bigger National firms.

We start by decomposing the economic activity of 2007 National firms by the year that firms started. ${ }^{9}$ In terms of the number of establishments, we find that the majority of National firms in 2007 started in 1977 or earlier. When we weight by economic activity (employment or real sales), the oldest firms are even more dominant. The firms from birth cohorts later than 1977 account for about 30\% of activity for 2007 National chains. Of this, a small fraction of the National activity in 2007 is due to entrants since 2002 (less than 5\%). ${ }^{10}$

We examine the evolution of National firms more closely by considering the status of these firms in a preceding period. Table 4 provides summary statistics on the 1987-2007 cohorts

\footnotetext{
${ }^{9}$ More precisely, this is measuredby the first Economic Census in which they appear. Thus, the possible start years are 1977, 1982, 1987, 1992, 1997, 2002 or 2007.

${ }^{10}$ Since a firm is a legal entity that owns physical establishments, it is possible to define the first year of the firm using either the first appearance of the legal entity or of the oldest physical establishment that the firm owns. We find the same basic patterns hold when we define age of the firm using the age of the oldest establishment.
} 
of National firms by the firm's size in the preceding Economic Census. ${ }^{11}$ The last row of Panel A of Table 4 shows what the 439 National retail trade firms in 2007 looked like in 2002: 69\% were National firms (304 firms), 15\% were Regional firms (67 firms), 4\% were smaller than Regional (18 firms), 8\% were new firms through ownership changes (34 firms), and 4\% were new (16 firms). This example points to two features of National chains that we see more generally. First, it takes time for firms to become National firms. In any given Economic Census, less than $25 \%$ of National firms were newly formed as legal entities and less than $10 \%$ of National firms entered as entirely new firms with all new establishments since the previous Economic Census. Although the oldest firms dominate the 2007 National chains, only about half of those firms were National firms in 1977.

Second, there is a lot of persistence. In any given Census year, most National firms were National in the previous period. As noted above, 69\% of National firms in 2007 were National firms in 2002. This is not surprising given that we saw in Section 5 that National chains have very low exit rates. As the number of National firms has grown, incumbent National firms account for an increasing share of National firms each period. Of the National firms that had newly achieved National status, 50\% of National firms in 2007 were Regional in 2002. Most firms that grow to achieve National status do so gradually, advancing from the next largest chain size over the course of the five years between Economic Censuses.

Additionally, mergers and changes in the legal status of the firm play an important role in the addition of new National firms each period. Of the newly National firms in 2007, 25\% achieved National status by undergoing some sort of ownership change since 2002. Roughly two-thirds of all firms that achieve National status within the first five years of formation as a

\footnotetext{
${ }^{11}$ The 1977 cohort is excluded due to is sues with left-censoring and the 1982 cohort is excluded for disclosure avoidance purposes.
} 
legal entity are actually the product of an ownership change of some kind rather than a newly formed firm with all new establishments.

We provide additional insight into the expansion patterns of the National firms by examining the intensity of firm activity within states in Panel D of Table 4. Recall from Section 4 that the intensity of firm activity within states increases as firms expand across states. This monotonicity is also present within National chains based on the size of the National chain in the previous period. Firms that were Regional the period before becoming National operate more establishments per state (about ten) than firms that make the jump from Single, Local, or Divisional to National (about seven establishments per state). Firms that expand to National status within five years of birth are much less intensive in each state, with only about five establishments per state when they first appear in the Economic Census.

Firms that grow to National status more quickly follow a different strategy than firms that grow more gradually; “quick growers” open a few establishments across many states shortly after establishing the firm as a legal entity, while "gradual growers" put down more significant roots in each state. Ownership changes are an exception, as firms that appear first as National firms due to ownership changes are more intense within states on average than are firms that grew from Regional chains between Economic Censuses. This suggests that most ownership changes that yield National chains is the product of chains that already have significant local, regional, or even national presence prior to the organizational change that generate the new National firms.

Refining our focus on evolutionary paths, we distinguish between "gradual growers” and two types of "quick growers": those that became National through establishment births ("quick growers de novo”) and those that grew through ownership change or reorganization (“quick 
growers reorganization”). ${ }^{12}$ We examine the patterns of state intensity by these three types in Panel A of Table 5. We find that "quick growers de novo" have the lowest within-state saturation of the three evolutionary paths in all years. The relative within-state saturation of “quick growers reorganization” and "gradual growers” has changed over time. In earlier periods, "gradual growers" had higher within-state saturation but that has shifted over time so that "quick growers reorganization” have higher within-state saturation more recently.

Acquisition of existing establishments by continuing incumbent firms (so no ownership change or reorganization) also plays an important role in the growth of National firms. Panel B of Table 5 shows the cumulative totals of acquisitions and divestitures of establishments over 1977-2007 for all of the 2007 National firms. About three-quarters of 2007 National firms grew through acquiring at least one establishment over the 30-year period. About $40 \%$ of these acquisitions are quite large, totaling more than 100 establishments over the 30-year period, with over 10\% of all 2007 National firms acquiring more than 500 pre-existing establishments. About one-third of the 2007 National firms had at least one divestiture over the 30-year period. Most of these divestitures were relatively small: about half were for 10 or fewer establishments.

In the preceding exercises, we have established that the "how we got here" for National chains in retail trade is mostly through gradual growth of firms. Most National chain firms in 2007 were National chains in 2002. However, the newly National firms form an interesting component of the 2007 National chains. Most of these were chains that grew from Regional in the previous five years, some were from recent ownership change or reorganizations, and a very few represent very rapid growth of de novo firms. These "quick growers de novo" appear to

\footnotetext{
${ }^{12}$ For this analysis, we consider the sample of all firms that were not National firms in 1977. Due to the leftcens ored nature of our sample, we cannot determine the growth paths of firms that achieved National status in or before 1977. As with our discussion of restructuring, we define a firm birth as a legal entity appearing in its first Economic Census, with all as sociated establishments also responding for the first time.
} 
follow a different evolutionary path than the "gradual growers" or "quick growers

reorganization” since they are much less likely to saturate a location before becoming National.

\section{Productivity analysis}

We next examine the productivity dynamics of retail chains. Recall that Foster et al. (2006) found that the large productivity gap between exiting low productivity single-unit establishments and entering high productivity establishments from large, national chains played an important role in retail trade dynamics. We build on this work by examining (withinindustry) labor productivity measures by chain type. Specifically, Figure 6 shows the firm-level employment-weighted mean labor productivity by chain type. The measures reflect deviations from employment-weighted industry-mean productivity so that we focus only on withinindustry variation. The general pattern over all years is that productivity is monotonically increasing in chain size up to the Regional chain level. ${ }^{13}$ Note, however, that National chains frequently exhibit productivity lower than Regional chains. An empirical regularity in the US across industry sectors is that the productivity of a business is a good predictor of its future survival and growth (see Syverson (2011) for a survey of the relevant literature). Productivity that is monotonically increasing over chain size is suggestive of some of these growth and survival dynamics. Thus, it may be that Regional chain productivity is high because of those large, productive chains that are in a transitory state before achieving National status.

We look into these dynamics by examining the productivity of Regional chains over their subsequent evolution. Table 6 shows the productivity of Regional chains in the subsequent period grouped by four basic outcomes: death, retrenchment (Single, Local, or Divisional),

\footnotetext{
${ }^{13}$ We calculate these statistics at firm and establishment levels using simple mean and employment-weighted means. We report only the firm-level, employment-weighted mean, but all measures show that productivity is monotonically increasing in chain size up to the Regional chain level.
} 
stasis (Regional), and growth (National). Three basic patterns emerge from Table 6. First, Regional firms that subsequently die in the next period are low productivity. Second, Regional firms that subsequently grow enough that in the next period they are National chains are high productivity. Third, Regional firms that subsequently face significant retrenchment (becoming Single or Local) are also relatively low productivity. Patterns are less clear for firms that face stasis (remain Regional) or mild retrenchment (become Divisional).

\section{Industry Analysis}

We now turn to industry-level analysis to examine these different paths in greater depth. We consider four retail industries: General Merchandising, Food stores, Apparel stores, and Restaurants. General Merchandising stores have the capacity to sell a wide variety of new goods in a single store while Food, Apparel stores are more specialized. Restaurants differ in that they bundle together goods and services in one location. The industry composition of National chains changes dramatically over our period of analysis. Figure 7 shows the National chains' shares of economic activity by industry. In terms of shares of economic activity, the main changes are the reduced dominance of General Merchandise and the rise in Apparel. The share of National chain employment falls from 52\% to $26 \%$ for General Merchandise and rises from 5\% to 14\% for Apparel from 1977 to 2007. (Patterns in real sales are similar but less stark in terms of the changing shares of General Merchandise and Apparel.) This is not to say that economic activity declines in General Merchandise, but rather to say that its dominance is diminished. Figure 8 shows summary measures for these four industries. ${ }^{14}$ The number of National chain firms in the Food Store and General Merchandise industries remains relatively

\footnotetext{
${ }^{14}$ Food store statistics in 1987 are suppressed to avoid disclosure.
} 
constant over the period (about 15 firms and 20 firms respectively), but the numbers of National chain firms in Restaurants and Apparel surge from a little over 40 in 1977 to over 70 (Restaurants) and 140 (Apparel) in 2007. Of the four industries, Apparel shows the largest increase in the number of stores in National chains while the number of General Merchandise and Food Stores exhibit only modest increases. Employment in National Chains is growing in all four industries. For General Merchandise and Food Stores, this suggests that existing firms could be replacing older, smaller establishments with newer, larger ones or expanding existing establishments. ${ }^{15}$ Alternatively new, more employment-intens ive National chains could be supplanting older, less employment-intensive chains in the General Merchandise and Food Store industries.

Figure 9 shows the share of employment by chain type for these four important industries over time. While the importance of National chains is growing for all of these industries, the industries still look very different in 2007. At one extreme is Food Stores where Single firms coexist with National chains and at the other extreme is General Merchandise stores where National chains dominate. ${ }^{16}$ Activity in Restaurants is increasingly in chains, but Single firms remain close to the dominant form (a little less than 50\%) in 2007. Apparel stores have undergone a dramatic change; the share of Apparel employment accounted for by National chains rises from $20 \%$ to $70 \%$ over $1977-2007$. Clearly one of the factors underlying the rise of

\footnotetext{
${ }^{15}$ A recurring theme in discussions about retail trade is the adoption of technologies that reduce staffing and customer-service models that increase staffing. Sieling, Friedman, and Dumas (2001) note this in their discussion of specialized departments of grocery stores. Similarly, Schulz(2014) notes Macy’s strategy of “Magic Selling” which requires training staff to be more cus tomer aware.

${ }^{16}$ In 2007, employment in National chains is evenly distributed across chain types for Food Stores but is about 89\% of employment in General Merchandise. Jarmin et al. (2009) found a similar pattern of coexistence for some industries and dominance in others.
} 
National chains reflects the changes within the Apparel industry. ${ }^{17}$

Figure 10 shows the within-state intensity of National chains by industry over time. Food Stores become less intense over time: within-state saturation drops from about 30 establishments per state to about 20 establishments per state. Sieling, Friedman, and Dumas (2001) characterize this industry as in decline as consumers shift away from conventional grocery stores to megastores or convenience stores. ${ }^{18}$ Schulz (2014) argues that there are no true National grocery store chains with the exception of Walmart.

In contrast, General Merchandise chains nearly double the average number of establishments per state from about 20 to 45 between 1977 and 2007. Within-state saturation of National chain Restaurants fluctuates somewhat over the sample period, but increases slightly to about 20 restaurants per state by 2007. The within-state saturation of National Apparel chains is relatively constant and low (at about 10 stores per state) over the period in which we have seen the number of firms and establishments and employment grow for National Apparel firms. This suggests that National Apparel chains are focusing on increasing the geographic scope of operations rather than saturation. In fact, the average number of states covered by a National Apparel chain increases from 29 in 1977 to 34 in 2007. The increase is essentially monotonic and accelerates after 1992. It appears that the within-state intensity of National chains in the Apparel industry is kept lower by new entrants who locate in a relatively small number of locations within a new state before expanding to the next. The same arguments may also apply to Restaurants.

\footnotetext{
${ }^{17}$ Sieling et al. (2001) note about Apparel stores “...thegeneral trend was towards fewer but larger sized establishments offering a greater variety of merchandise while at the same time offering more customer service in terms of increased sales personnel (p.8).”

${ }^{18}$ Sieling et al. (2001) note conventional grocery stores accounted for $43 \%$ of all consumers expenditures for food at home in 1988, but that this dropped to 13\% by 1998 (p.7). Convenience stores are included in Food Stores, but many convenience stores are franchises rather than chain stores.
} 
We now look at the paths to evolution to a National chain in 2007, starting by again considering two types of paths to becoming a National chain: "quick growers" and "gradual growers.” Figure 11 presents the industry shares of economic activity by time to achieve National status. ${ }^{19}$ Apparel Stores and Restaurants have the largest shares of employment of firms that are "quick growers" and form a large share of total revenue by firms that are "quick growers.” "Gradual growers" are dominated by a group of "Other” industries that includes General Merchandise stores, Food Stores, and others.

We can again distinguish between two groups within "quick growers": those firms that grew by adding new establishments (“quick growers de novo”) and those that grew through reorganization activities (“quick growers reorganization”). Apparel stores account for about 20$25 \%$ of employment for all "quick growers," but form a slightly smaller share of revenue of “quick growers de novo.” Restaurants account for nearly 50\% of employment and roughly 25\% of revenue for “quick growers reorganization.” Looking within 2007 National Apparel stores, employment shares are as follows: 62\% are "gradual growers;" 33\% are "quick growers reorganization;” and 5\% are "quick growers de novo.” ${ }^{20}$ Recall also that "quick growers” generally have lower within state intensity than do firms that achieve National status more gradually.

Putting this all together for industries, we find that underlying the general rise of National chains in the retail trade sector are diverse paths for National chains across industries. When people talk about National retail trade chains, they often have in mind General Merchandise stores. From our evidence, it is clear to see why this is the case. Not only are National chains dominated (albeit less so over time) by General Merchandise stores, most

\footnotetext{
${ }^{19}$ Industry detail is suppressed in Figure 11 due to disclosure avoidance requirements.

${ }^{20}$ Roughly the same patterns play out for revenue.
} 
General Merchandise activity occurs at National chains. Another industry, Apparel, seems to be headed in the direction of General Merchandise stores. Interestingly, Apparel stores have made the leap into National chains via a combination of "gradual growers" and "quick growers." The share of National Apparel stores that are accounted for by "quick growers" rather than "gradual growers" is larger than the share of "quick growers" in any other industry of National chains. These "quick growers" include both de novo firms and reorganizations.

National chains also became more important in Restaurants and Food Stores, but these look very different from General Merchandise and Apparel. While National chains became more important among Restaurants, it is still the case that many restaurants are single-location firms or firms that operate over a small geography, which would include many franchises of national or international brands. This coexistence of different types of firms is even more striking in the Food Stores industry. Even with the increasing share of National chains in Food Stores, by 2007 employment is basically evenly divided over all five chain types. Thus, in some industries the rise of National chains seems to be crowding out other forms of organization, whereas in other industries it seems to be just one type of organization.

\section{Conclusions and Future Research}

The growth of chain firms in the US retail trade sector documented in the literature is mostly a result of the growth of National firms. National retail trade firms (firms with establishments in at least 18 states) increasingly dominate the US retail trade sector. Even though there are almost one million Single firms to fewer than 500 National firms, National firms accounted for about the same amount of employment and sales as their much smaller Single firm counterparts in 2007. The growth of smaller chains (operating in fewer than 18 
states) has been far more modest. The growth of the sales and employment by National firms is driven by an increase in the number and size of National firms.

National firms are very large in terms of number of establishments, employment, and sales. The average size of a National firm is almost 15,000 workers with about 200 establishments which compares to an average of around 10 workers for Single firms. Moreover, amongst the National firms, the size distribution is very skewed. The average worker who works for a National firm on average works for a firm with about 240,000 workers. This contrasts with the average worker for a Single firm who works for a firm of around 38 workers.

The entry rate for Single firms has declined over the 1977 to 2007 period but it still remains consistently higher (on an employment-weighted basis) than the rate of entry for establishments of National firms. The latter is much higher than the entry rate of National firms. Much of the job creation of National firms is due to new establishments rather than new firms. Another factor contributing to the decline of the contribution of Single firms is that the job destruction and exit rate of Single firms is much higher than the corresponding rate for establishments of National firms. Once created, an establishment for a National firm is much more stable in the sense that it is much less likely to contract and exit. It is this latter factor that is especially important for the decline in Single firms compared to National firms.

National firms are much more productive than Single firms that are operating within the same industry. Our findings thus confirm the findings of Foster et al. (2006) that the shift from single unit firms to large, national chains is consistent with productivity-enhancing reallocation and restructuring of the retail trade sector. We also find that Regional firms have higher average productivity than National firms, but this is because Regional firms include high productivity firms on their way to becoming National firms.

The large differences in the job destruction and exit patterns for Single versus National 
firms are part of the underlying story of the decline in overall firm volatility documented by Davis et al. (2007) and Decker et al. (2014a, b). The greater stability and the rising share of National firms have implied substantially lower firm and establishment volatility for the overall retail trade sector. Putting these results together with the much higher productivity of National firms compared to Single firms, the decline in volatility in retail trade has been if anything productivity enhancing. This is because the decline in volatility has been associated with reallocation to firm types that are both more productive and less volatile.

The National firms in 2007 are predominately firms that have existed for more than 30 years, with only about 30\% of 2007 National firms less than 30 years old. Most National firms achieved that status gradually, but others grew more rapidly or were created through reorganization. The primary means of expansion for National firms is via establishment entry. However, we find that about 70\% of all 2007 National firms have at least one acquisition between 1977 and 2007.

Underlying the general rise of National chains in the retail trade sector are diverse paths for National chains across industries. We focused on four industries in particular: General Merchandise, Food Stores, Apparel, and Restaurants. All four industries saw a rise in National chains, but there were differences. Apparel is joining General Merchandise in being dominated by National chains. The rapid rise in National firms for Apparel is due to a different evolutionary path than General Merchandise. The latter is dominated more by gradual growers while Apparel has more rapid growers. While National chains also became more important among Restaurants and Food Stores, these industries look very different from General Merchandise and Apparel. It is still the case that many Restaurants are single location firms or firms that operate over a small geography. Activity in Food Stores is almost evenly divided across the five chain types. 
As the title of the paper suggests, this is a largely descriptive paper focusing on the "how" rather than the "why" National chains are increasingly important. In the spirit of Holmes (2011), there must be economic factors that help account for the different patterns observed across birth cohorts, industries and firm types. Holmes suggests, for example, that there are potential tradeoffs between economies of density and expanding to the highest quality retail sites.

Another factor that is likely playing a role is the IT revolution which has helped National firms like Walmart develop sophisticated inventory management and distribution networks that are critical for being able to take advantage of the economies of scale of National firms. We do not address this latter question directly, but our evidence should be helpful in evaluating such questions. While Jarmin et al. (2004, 2009) note that the rising share of large, national firms predates the IT revolution, our evidence suggests that there has been acceleration in the growth of National firms since the mid 1980s. But it is interesting that while Single firms have exhibited a declining entry rate, it is still quite high and much higher than the entry rate of establishments of other groups over this entire period. So whatever the driving force is, it has not changed the fact that Single firms continue to enter at a high rate. Any IT-based explanation would need to take into account the entry, exit, job creation and job destruction patterns across chain types we have detected. 


\section{References}

Basker, Emek (2005), 'Job Creation or Destruction? Labor Market Effects of Walmart Expansion', Review of Economics and Statistics, 87(1), 174-83.

Basker, Emek and Michael Noel (2009), 'The Evolving Food Chain: Competitive Effects of Walmart's Entry into the Supermarket Industry', Journal of Economics and Management Strategy, 18(4), 977-1009.

Basker, Emek, Shawn Klimek, and Pham Hoang Van (2012), 'Supersize It: The Growth of Retail Chains and the Rise of the 'Big-Box' Store', Journal of Economics and Management Strategy, 21(3), 541-82.

Davis, Steven, John Haltiwanger, and Scott Schuh (1996), Job Creation and Destruction, Cambridge, MA, USA: MIT Press.

Davis, Steven, John Haltiwanger, Ron Jarmin, and Javier Miranda (2007), 'Volatility in Business Growth Rates: Publicly Traded versus Privately Held Firms', NBER Macroeconomics Annual 2006, 21, 107-180.

Decker, Ryan, John Haltiwanger, Ron S. Jarmin, and Javier Miranda (2014a), 'The Role of Entrepreneurship in US Job Creation and Economic Dynamism', Journal of Economic Perspectives, 28(3), 3-24.

Decker, Ryan, John Haltiwanger, Ron S. Jarmin, and Javier Miranda (2014b), 'The Secular Decline of Business Dynamism in the United States', working paper, University of Maryland (June).

Foster, Lucia, John Haltiwanger, and C.J. Krizan (2006), 'Market Selection, Reallocation and Restructuring in the US Retail Trade Sector in the 1990s', The Review of Economics and Statistics, 88(4), 748-758.

Haltiwanger, John, Ron S. Jarmin, and C.J. Krizan (2010), 'Mom-and-Pop Meet BigBox: Complements or Substitutes?', Journal of Urban Economics, 67(1), 116134.

Haltiwanger, John, Ron S. Jarmin, and Javier Miranda (2013), 'Who Creates Jobs? Small vs. Large vs. Young', Review of Economics and Statistics, 95(2), 347-361.

Haskel, Jonathan and Raffaella Sadun (2009), 'Entry, Exit and Labour Productivity in U.K. Retailing: Evidence from Micro Data', in Timothy J. Dunne, J. Bradford Jensen and Mark J. Roberts (eds.), Producer Dynamics, Chicago, IL, USA: University of Chicago Press, pp.271-302.

Holmes, Thomas J. (2011), 'The Diffusion of Walmart and Economies of Density', Econometrica, 79(1), 253-302. 
Jarmin, Ron S. and Javier Miranda (2002), ‘The Longitudinal Business Database’, Center for Economic Studies Working Paper No. 02-17.

Jarmin, Ron S., Shawn Klimek, and Javier Miranda (2009), 'The Role of Retail Chains: National, Regional, and Industry Results', in Timothy J. Dunne, J. Bradford Jensen and Mark J. Roberts (eds.), Producer Dynamics, Chicago, IL, USA: University of Chicago Press, pp.237-262.

Jarmin, Ron S., Shawn Klimek, and Javier Miranda (2004), 'Firm Entry and Exit in the US Retail Sector, 1977-1997’, Center for Economic Studies Working Paper No. 04-17.

Schulz, David P. (2014), 'Top 100 Retailers', available at https://nrf.com/news/top-100-retailers (accessed 30 November 2014).

Sieling, Mark, Brian Friedman, and Mark Dumas (2001), 'Labor Productivity in the Retail Trade Industry, 1987-99,' Monthly Labor Review, 124(12), 3-14.

Syverson, Chad (2011), 'What Determines Productivity?' Journal of Economic Literature, 49(2): 326-65. 


\section{Data Appendix}

\section{Summary Statis tics for the Retail Trade Sector}

Table A1: Summary Statistics for the Retail Trade Industry, 1977-2002

\begin{tabular}{lrrr}
\hline Year & Establishments & Employment & Sales \\
SIC Basis & & & \\
1977 & $1,303,621$ & $13,040,082$ & $699,634,863$ \\
1982 & $1,330,316$ & $14,467,813$ & $1,039,028,742$ \\
1987 & $1,503,593$ & $17,779,942$ & $1,493,308,759$ \\
1992 & $1,526,215$ & $18,407,453$ & $1,894,880,209$ \\
1997 & $1,561,195$ & $21,165,862$ & $2,545,881,473$ \\
NAICS Basis & & & \\
1997 & $1,118,447$ & $13,991,103$ & $2,460,886,012$ \\
2002 & $1,114,637$ & $14,647,675$ & $3,056,421,997$ \\
2007 & $1,128,112$ & $15,515,396$ & $3,917,663,456$
\end{tabular}

Source: Census of Retail Trade, various years. The 1997 SIC data are from the Census website.

\section{Industry Coding Issues}

There are issues concerning developing a SIC-based version of retail trade in 2002 and 2007. The SIC definition of retail trade contains some industries not in the NAICS definition of retail trade (e.g., Eating and Drinking Places). On the other side, the NAICS definition of retail trade contains some industries not in the SIC definition (e.g., wholesalers selling as retailers and repair shops). We would like to remove these NAICS-only establishments from our sample but this is not possible. We can only identify establishments that have been in operation since 1997 for our SIC-based measure. This means that we still have extra establishments in our version of the 2002 and 2007 SIC-based CRTs due to unclassifiable births. These births are linked from their NAICS industries to SIC industries using a concordance that admits multiple SIC matches for each NAICS industry. If any one of the matches is in the SIC retail definition, we consider the establishment to be in an SIC retail industry for the purpose of inclusion in our sample.

In order to establish consistent industry analysis over time, we use time-consistent NAICS codes developed by Fort and Klimek (FK-NAICS) for all industry-level analysis. As noted above, there is imperfect overlap between the SIC and NAICS definitions of retail. Prior to 2002, some establishments and firms that are considered retail under the SIC definition may have FK-NAICS codes that are not considered retail in the NAICS definition. In 2002 and 2007, because we match new establishments to SIC industries using a concordance, it is possible that a non-retail FK-NAICS code would be retained in the sample due to the existence of at least one match to a retail SIC code. As noted above, Restaurants are classified as retail under SIC but not under NAICS. The reader should be aware that when we use the term "other" in any industrylevel analysis, we are not strictly referring to other NAICS-based retail, but in fact any NAICS industry that is not expressly noted in the figure (specifically Figures 7 and 11). 
Table 1: Summary Statistics on Chain Types

\begin{tabular}{|c|c|c|c|c|c|}
\hline & Single & Local & Divisional & Regional & National \\
\hline \multicolumn{6}{|c|}{ A: Total Number } \\
\hline \multicolumn{6}{|l|}{ Firms } \\
\hline 1977 & 929,693 & 49,078 & 5,112 & 548 & 201 \\
\hline 2007 & 956,302 & 46,597 & 6,507 & 747 & 439 \\
\hline \multicolumn{6}{|c|}{ Establishments } \\
\hline 1977 & 929,693 & 139,957 & 52,649 & 50,944 & 95,129 \\
\hline 2007 & $956,302^{21}$ & 156,449 & 80,895 & 63,687 & 285,677 \\
\hline \multicolumn{6}{|c|}{ B: Average Per Firm } \\
\hline \multicolumn{6}{|c|}{ Establishments } \\
\hline 1977 & 1 & 3 & 10 & 93 & 473 \\
\hline 2007 & 1 & 3 & 12 & 85 & 651 \\
\hline \multicolumn{6}{|c|}{ Employees } \\
\hline 1977 & 7 & 38 & 192 & 1,886 & 13,198 \\
\hline 2007 & 9 & 68 & 315 & 2,394 & 19,060 \\
\hline \multicolumn{6}{|c|}{ Real Sales } \\
\hline 1977 & 1,211 & 7,143 & 36,766 & 386,106 & 2,186,039 \\
\hline 2007 & 1,452 & 11,290 & 51,782 & 476,974 & $3,244,515$ \\
\hline \multicolumn{6}{|c|}{ Coworker Mean } \\
\hline 1977 & 26 & 607 & 2,666 & 13,597 & 98,899 \\
\hline \multirow[t]{2}{*}{2007} & 38 & 1,456 & 13,972 & 21,177 & 240,422 \\
\hline & \multicolumn{5}{|c|}{ C: Average Number of Establishments Per State } \\
\hline 1977 & 1.0 & 2.9 & 4.0 & 9.0 & 14.1 \\
\hline 1982 & 1.0 & 2.8 & 4.1 & 8.8 & 16.6 \\
\hline 1987 & 1.0 & 2.9 & 4.1 & 8.9 & 17.5 \\
\hline 1992 & 1.0 & 2.9 & 4.3 & 8.9 & 15.0 \\
\hline 1997 & 1.0 & 3.0 & 4.6 & 8.4 & 13.8 \\
\hline 2002 & 1.0 & 3.2 & 4.8 & 8.2 & 15.4 \\
\hline 2007 & 1.0 & 3.4 & 4.8 & 8.6 & 16.6 \\
\hline $\begin{array}{l}\text { Source } \\
\text { Note: R }\end{array}$ & $\begin{array}{l}\text {-level data. } \\
\text { plied over en }\end{array}$ & time perio & & & \\
\hline
\end{tabular}

\footnotetext{
${ }^{21}$ The samples for 2002 and 2007 the Census of Retail Trade includes a small number of firms that are identified as single-unit but havetwo affiliated es tablishments. These firms are treated as single-unit for the purpose of our analysis.
} 
Table 2: Job Creation and Entry by Chain Types

\begin{tabular}{|c|c|c|c|c|c|}
\hline & Single & Local & Divisional & Regional & National \\
\hline \multicolumn{6}{|c|}{ A: Average Share of Job Creation Accounted for by Entry } \\
\hline \multicolumn{6}{|c|}{ Establishment-level Job Creation by Establishment Entry } \\
\hline 1977-1987 & 78.3 & 76.2 & 77.9 & 76.2 & 76.6 \\
\hline 1987-1997 & 76.9 & 72.8 & 75.8 & 75.9 & 74.5 \\
\hline $1997-2007$ & 76.4 & 70.8 & 76.7 & 76.1 & 74.4 \\
\hline \multicolumn{6}{|c|}{ Establishment-level Job Creation by Firm Entry } \\
\hline 1977-1987 & 78.1 & 42.3 & 17.5 & 5.2 & 0.2 \\
\hline 1987-1997 & 76.7 & 35.0 & 15.4 & 4.0 & 1.0 \\
\hline 1997-2007 & 75.9 & 38.6 & 17.5 & 5.2 & 2.0 \\
\hline \multicolumn{6}{|c|}{ Firm-level Job Creation by Firm Entry } \\
\hline 1977-1987 & 78.2 & 49.8 & 22.9 & 7.9 & 0.3 \\
\hline 1987-1997 & 76.9 & 43.9 & 22.2 & 6.3 & 1.9 \\
\hline 1997-2007 & 76.2 & 47.5 & 25.9 & 9.2 & 3.3 \\
\hline \multicolumn{6}{|c|}{ B: Average Five-Year Entry Rates } \\
\hline \multicolumn{6}{|c|}{ Employment-weighted Establishment-level } \\
\hline 1977-1987 & 47.0 & 44.8 & 44.1 & 39.3 & 35.5 \\
\hline 1987-1997 & 40.3 & 32.0 & 33.8 & 33.1 & 34.2 \\
\hline 1997-2007 & 39.6 & 28.9 & 28.5 & 26.6 & 29.2 \\
\hline \multicolumn{6}{|c|}{ Employment-weighted Firm-level } \\
\hline $1977-1987$ & 46.7 & 24.5 & 9.8 & 2.7 & 0.1 \\
\hline 1987-1997 & 40.1 & 15.1 & 6.8 & 1.8 & 0.5 \\
\hline 1997-2007 & 39.1 & 15.6 & 6.5 & 1.8 & 0.9 \\
\hline \multicolumn{6}{|c|}{ Establishment-level } \\
\hline 1977-1987 & 49.6 & 47.6 & 48.9 & 41.8 & 46.3 \\
\hline 1987-1997 & 47.5 & 34.8 & 36.5 & 36.0 & 39.2 \\
\hline $1997-2007$ & 47.3 & 31.7 & 33.2 & 32.9 & 36.0 \\
\hline \multicolumn{6}{|l|}{ Firm-level } \\
\hline 1977-1987 & 49.4 & 32.4 & 27.1 & 11.2 & 2.4 \\
\hline 1987-1997 & 47.4 & 20.4 & 19.6 & 11.9 & 7.6 \\
\hline 1997-2007 & 47.0 & 22.3 & 21.3 & 11.5 & 3.5 \\
\hline $\begin{array}{l}\text { Note: Job flow } \\
\text { over five-y ear p } \\
\text { averaged), and }\end{array}$ & $\begin{array}{l}\text { e for five } \\
\text { ig (1977. } \\
2002-200\end{array}$ & $\begin{array}{l}\text { ar horizol } \\
\text { and } 1982 \\
\text { veraged) }\end{array}$ & $\begin{array}{l}\text { s. Reported st } \\
87 \text { averaged), } \\
\text { f the sample p }\end{array}$ & $\begin{array}{l}\text { tics in table a } \\
\text { ddle (1987-9 } \\
\text { od. }\end{array}$ & $\begin{array}{l}\text { verages } \\
\text { d 1992-97 }\end{array}$ \\
\hline
\end{tabular}


Table 3: Job Destruction and Exit by Chain Types

\begin{tabular}{|c|c|c|c|c|c|}
\hline & Single & Local & Divisional & Regional & National \\
\hline \multicolumn{6}{|c|}{ A: Average Share of Job Destruction Accounted for by Exit } \\
\hline \multicolumn{6}{|c|}{ Establishment-level Job Destruction by Establishment Exit } \\
\hline 1977-1987 & 80.6 & 71.8 & 67.5 & 67.9 & 59.4 \\
\hline 1987-1997 & 78.4 & 67.3 & 65.4 & 64.6 & 60.5 \\
\hline $1997-2007$ & 76.0 & 65.2 & 59.2 & 64.7 & 55.7 \\
\hline \multicolumn{6}{|c|}{ Establishment-level Job Destruction by Firm Exit } \\
\hline 1977-1987 & 80.2 & 48.2 & 31.1 & 18.8 & $\mathrm{D}$ \\
\hline 1987-1997 & 77.6 & 42.2 & 32.5 & 20.4 & 6.0 \\
\hline 1997-2007 & 75.0 & 42.1 & 27.8 & 23.3 & 13.5 \\
\hline \multicolumn{6}{|c|}{ Firm-level Job Destruction by Firm Exit } \\
\hline 1977-1987 & 80.3 & 61.5 & 53.5 & 46.5 & $\mathrm{D}$ \\
\hline 1987-1997 & 77.8 & 53.8 & 54.4 & 42.4 & 19.2 \\
\hline 1997-2007 & 75.3 & 52.9 & 43.6 & 40.8 & 33.7 \\
\hline \multicolumn{6}{|c|}{ B: Average Five-Year Exit Rates } \\
\hline \multicolumn{6}{|c|}{ Employment-weighted Establishment-level } \\
\hline $1977-1987$ & 39.1 & 28.3 & 21.4 & 20.5 & 17.3 \\
\hline 1987-1997 & 38.0 & 27.5 & 22.1 & 20.1 & 17.9 \\
\hline 1997-2007 & 34.0 & 24.0 & 19.3 & 23.0 & 15.3 \\
\hline \multicolumn{6}{|c|}{ Employment-weighted Firm-level } \\
\hline $1977-1987$ & 38.8 & 19.3 & 9.5 & 5.6 & $\mathrm{D}$ \\
\hline 1987-1997 & 37.7 & 17.2 & 10.9 & 6.3 & 1.8 \\
\hline 1997-2007 & 33.7 & 15.7 & 9.2 & 8.5 & 3.7 \\
\hline \multicolumn{6}{|c|}{ Establishment-level } \\
\hline 1977-1987 & 50.9 & 37.7 & 30.8 & 29.3 & 24.5 \\
\hline 1987-1997 & 47.9 & 38.1 & 33.2 & 30.7 & 29.2 \\
\hline $1997-2007$ & 42.9 & 32.4 & 28.6 & 30.3 & 25.8 \\
\hline \multicolumn{6}{|l|}{ Firm-level } \\
\hline 1977-1987 & 50.7 & 32.9 & 24.3 & 21.9 & $\mathrm{D}$ \\
\hline 1987-1997 & 47.8 & 31.3 & 28.1 & 23.5 & 14.4 \\
\hline 1997-2007 & 42.7 & 29.5 & 23.6 & 25.3 & 20.7 \\
\hline \multicolumn{6}{|c|}{$\begin{array}{l}\text { Note: Job flow and exit statistics are for five-y ear horizons. Rep orted statistics in table are averages } \\
\text { over five-y ear periods at the beginning (1977-82 and 1982-87 averaged), middle (1987-92 and 1992-97 } \\
\text { averaged), and end (1997-2002 and 2002-2007 averaged) of the sample period. } \\
\text { Cells that cannot be disclosed are denoted by “D”. }\end{array}$} \\
\hline
\end{tabular}


Table 4: National Chains by Chain Size in Previous Period

\begin{tabular}{|c|c|c|c|c|c|}
\hline & \multicolumn{4}{|c|}{ Size in Previous Period } & \multirow[b]{2}{*}{ National } \\
\hline & Reorganization & Birth & $\begin{array}{c}\text { Single/Local/ } \\
\text { Divisional }\end{array}$ & Regional & \\
\hline \multicolumn{6}{|c|}{ A. Number of Firms } \\
\hline 1987 & 34 & 12 & 15 & 64 & 148 \\
\hline 1992 & 49 & 28 & 20 & 62 & 191 \\
\hline 1997 & 39 & 29 & 36 & 87 & 242 \\
\hline 2002 & 30 & 16 & 19 & 88 & 285 \\
\hline 2007 & 34 & 16 & 18 & 67 & 304 \\
\hline \multicolumn{6}{|c|}{ B. Sales (in Millions of Dollars) } \\
\hline 1987 & 9.7 & 0.7 & 2.6 & 35.8 & 263.7 \\
\hline 1992 & 24.1 & 2.0 & 5.8 & 31.4 & 372.6 \\
\hline 1997 & 21.7 & 2.0 & 12.0 & 104.8 & 542.2 \\
\hline 2002 & 18.1 & 17.4 & 13.7 & 117.6 & 912.5 \\
\hline 2007 & 32.7 & 3.5 & 7.1 & 57.6 & 1,323.6 \\
\hline \multicolumn{6}{|c|}{ C. Employment (in Thousands) } \\
\hline 1987 & 177.3 & 7.7 & 35.6 & 416.3 & $3,492.0$ \\
\hline 1992 & 240.8 & 24.9 & 43.9 & 351.7 & $3,953.2$ \\
\hline 1997 & 345.6 & 17.7 & 17.2 & 647.1 & $4,954.8$ \\
\hline 2002 & 221.4 & 87.2 & 76.1 & 689.6 & $6,347.2$ \\
\hline 2007 & 201.5 & 28.0 & 61.0 & 339.3 & $7,737.4$ \\
\hline \multicolumn{6}{|c|}{ D. Average Number of Establishments per State } \\
\hline 1987 & 9.6 & 5.7 & 7.9 & 13.8 & 22.9 \\
\hline 1992 & 5.9 & 4.1 & 5.3 & 9.1 & 21.9 \\
\hline 1997 & 12.3 & 3.2 & 7.4 & 8.7 & 18.2 \\
\hline 2002 & 9.4 & 7.3 & 7.3 & 11.3 & 18.2 \\
\hline 2007 & 10.2 & 5.5 & 6.5 & 9.1 & 20.2 \\
\hline
\end{tabular}




\section{Table 5: Organizational Activities of Firms Becoming National Chains}

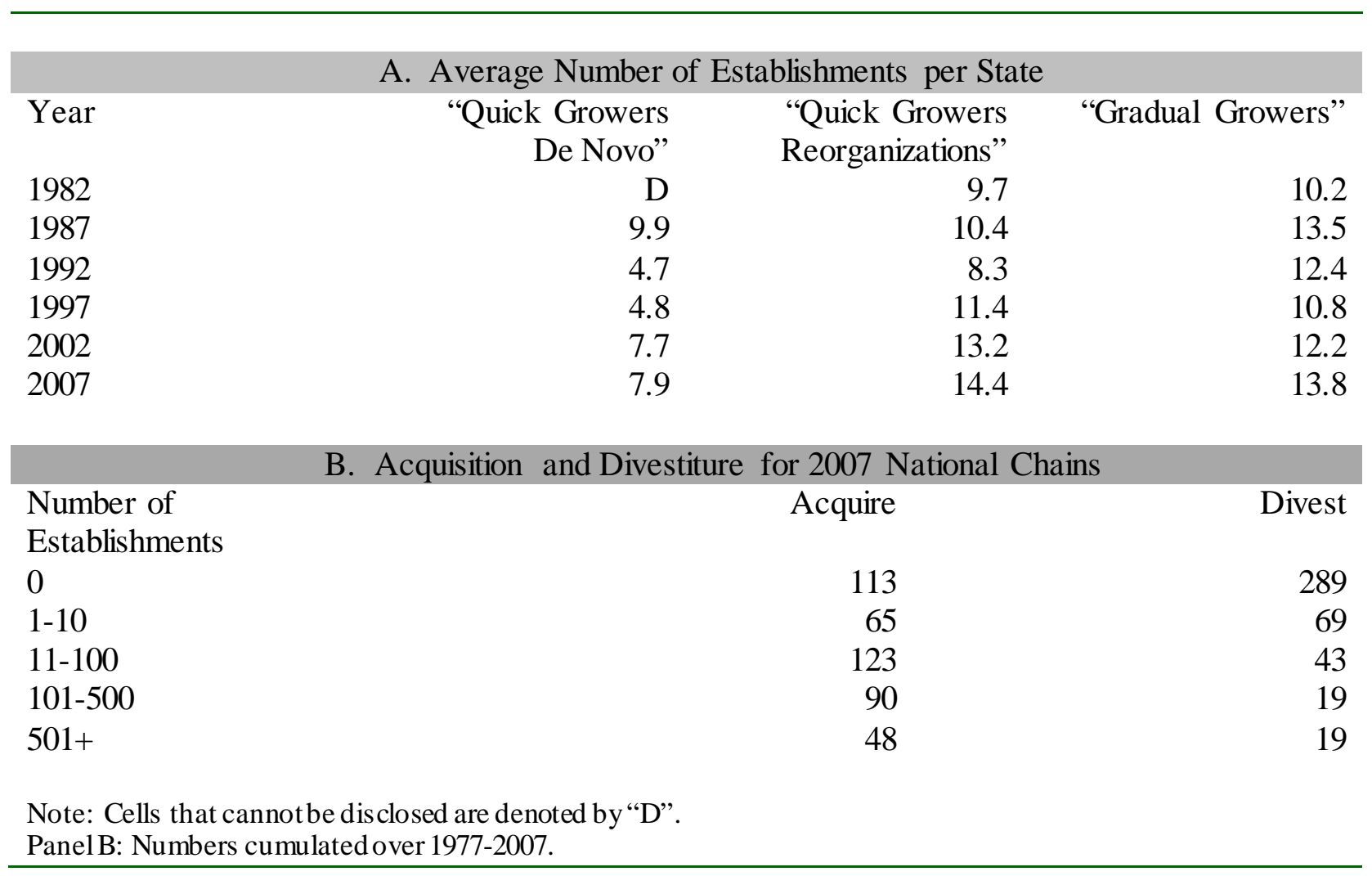




\section{Table 6: Productivity of Regional Chains by Chain Size in Subsequent Period}

\begin{tabular}{lcrcrr}
\hline & Death & Single/Local & Divisional & Regional & National \\
& Firm-level & Employment-weighted Mean & & \\
$1977-1982$ & 0.20 & 0.14 & 0.24 & 0.12 & 0.28 \\
$1982-1987$ & -0.22 & -0.04 & 0.14 & 0.16 & 0.21 \\
$1987-1992$ & -0.09 & 0.00 & 0.22 & 0.11 & 0.19 \\
$1992-1997$ & 0.06 & 0.05 & -0.01 & 0.04 & 0.30 \\
$1997-2002$ & -0.05 & 0.15 & -0.01 & 0.05 & 0.20 \\
$2002-2007$ & -0.14 & -0.01 & -0.04 & 0.13 & 0.16 \\
& & & & & \\
Note: Productivity is industry de-meaned. & & & & \\
\hline
\end{tabular}


Figure 1: Summary Statis tics for Retail Trade Sample, 1977-2007

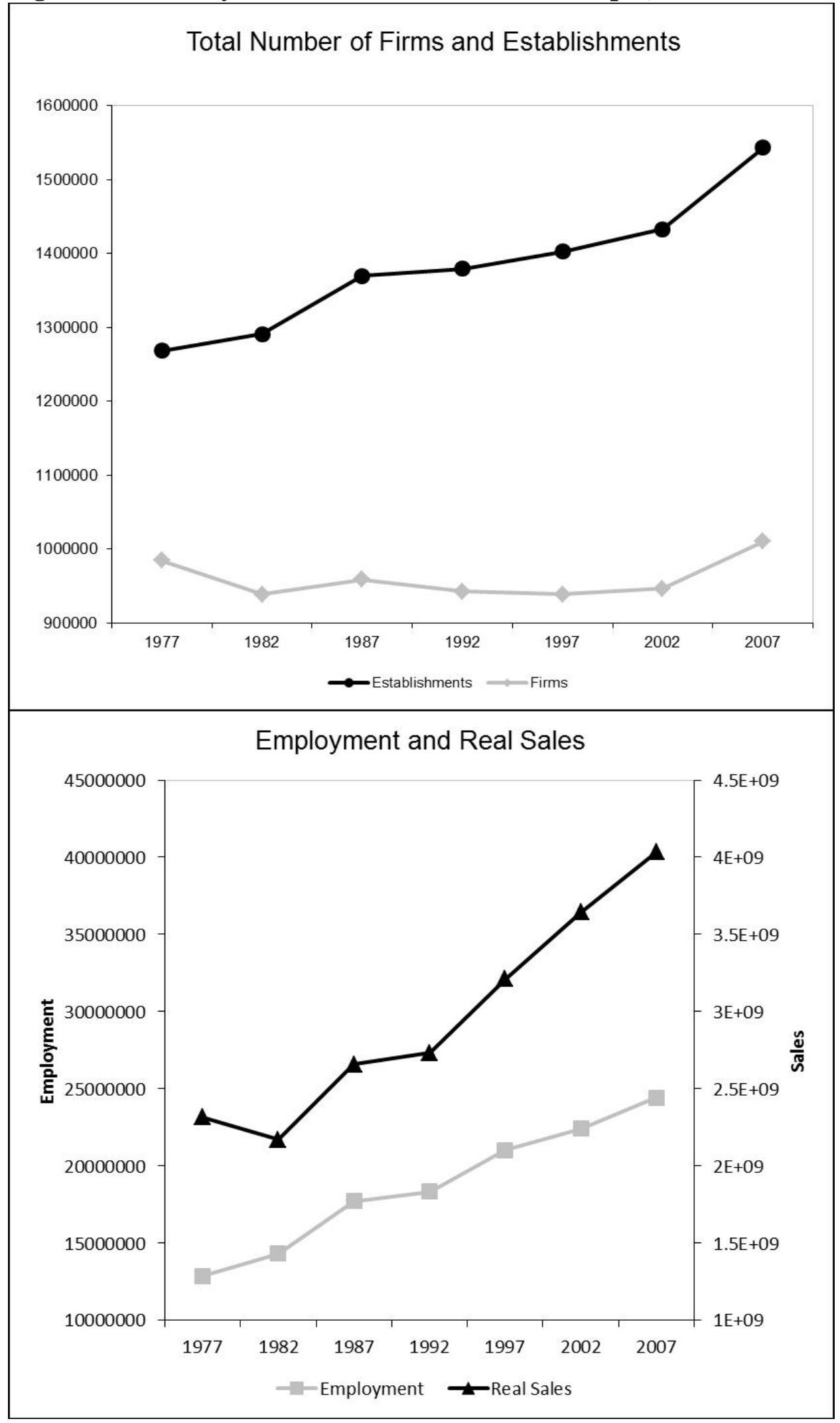


Figure 2: Total Employment and Real Sales by Firm and Chain Types

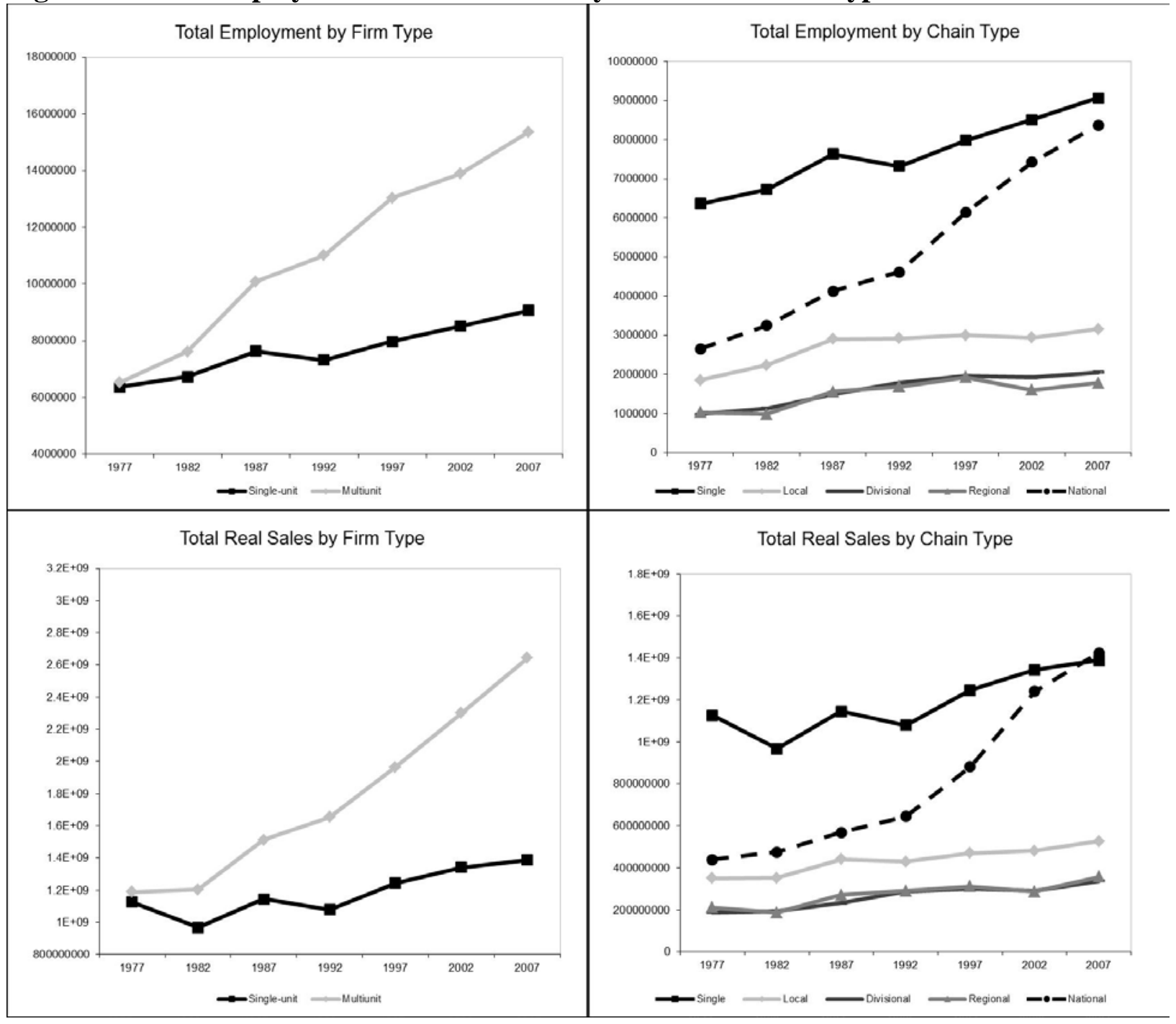


Figure 3: Number of States in National Chains (1977 versus 2007)

\section{Employment}

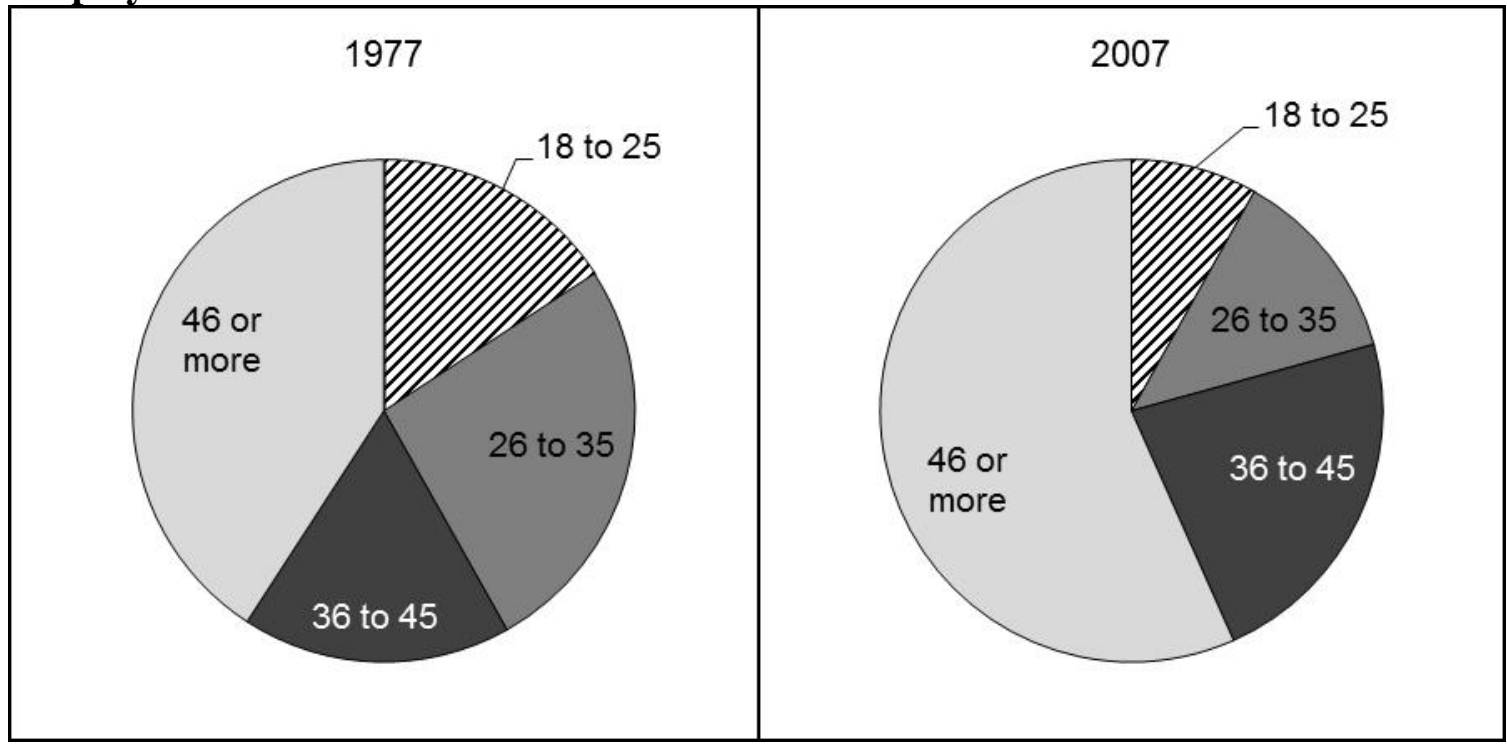

\section{Revenues}

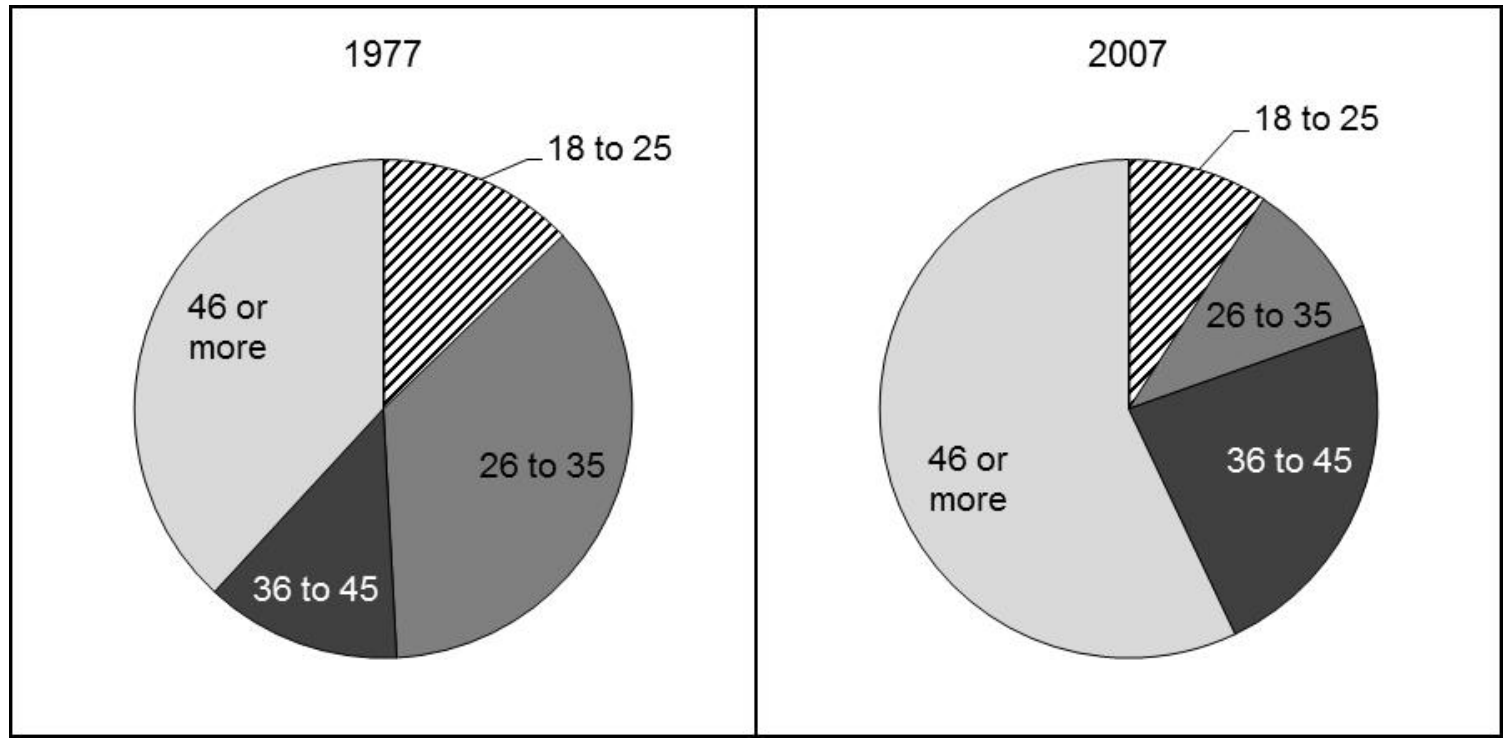


Figure 4: Job Creation and Destruction by Establishments and Chain Type

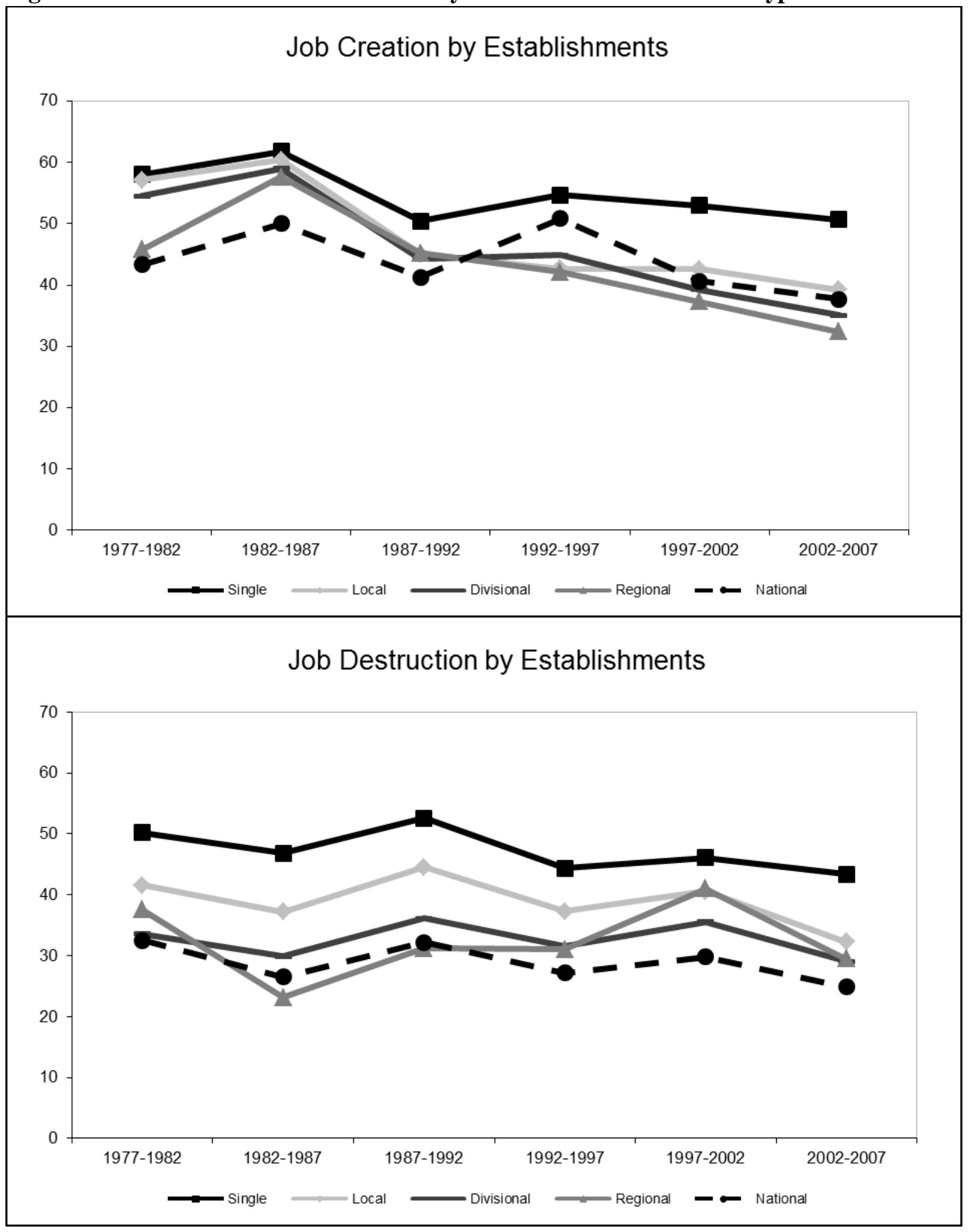


Figure 5: Job Creation and Destruction by Firms and Chain Type

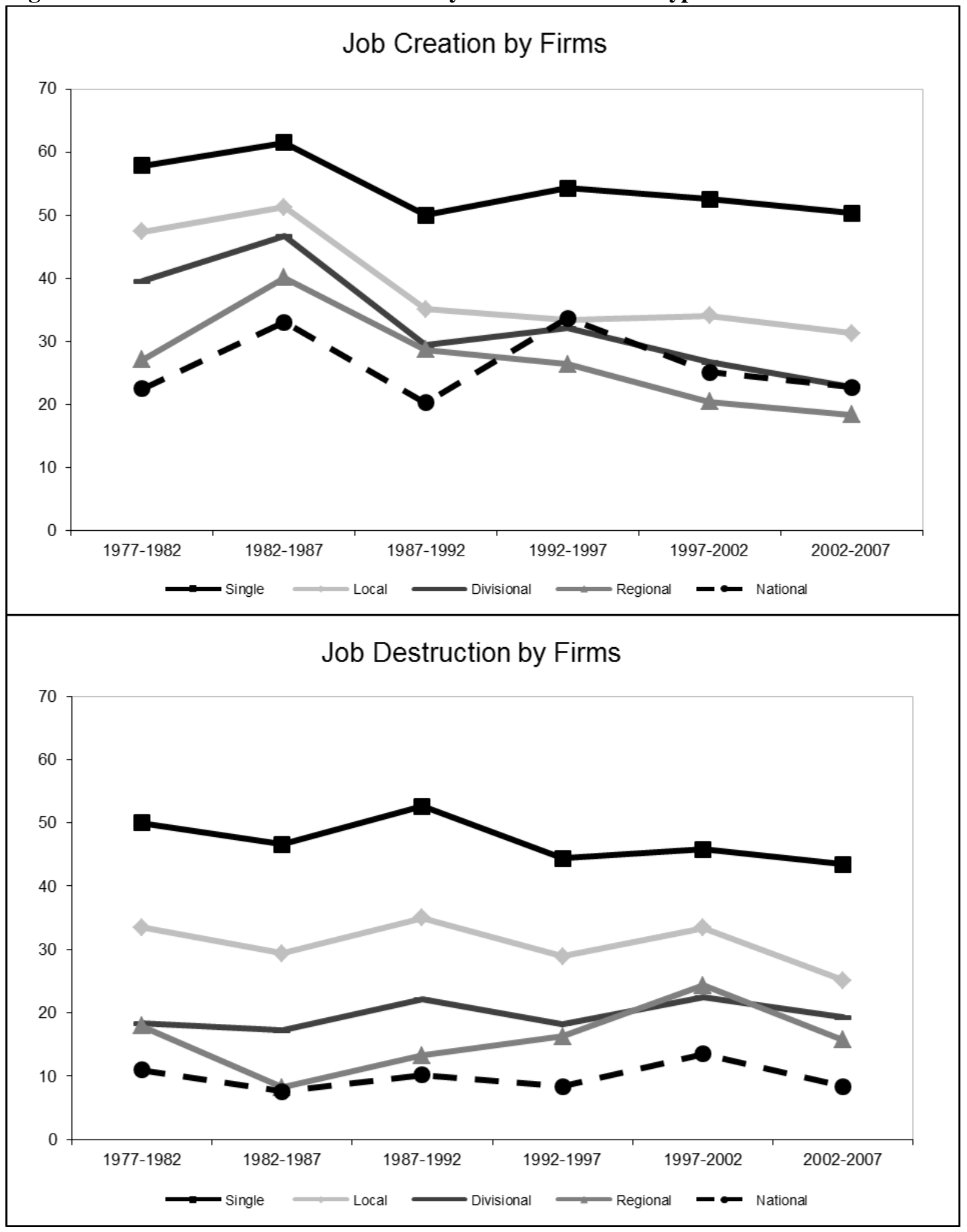


Figure 6: Employment-weighted Mean Firm-level Productivity by Chain Size

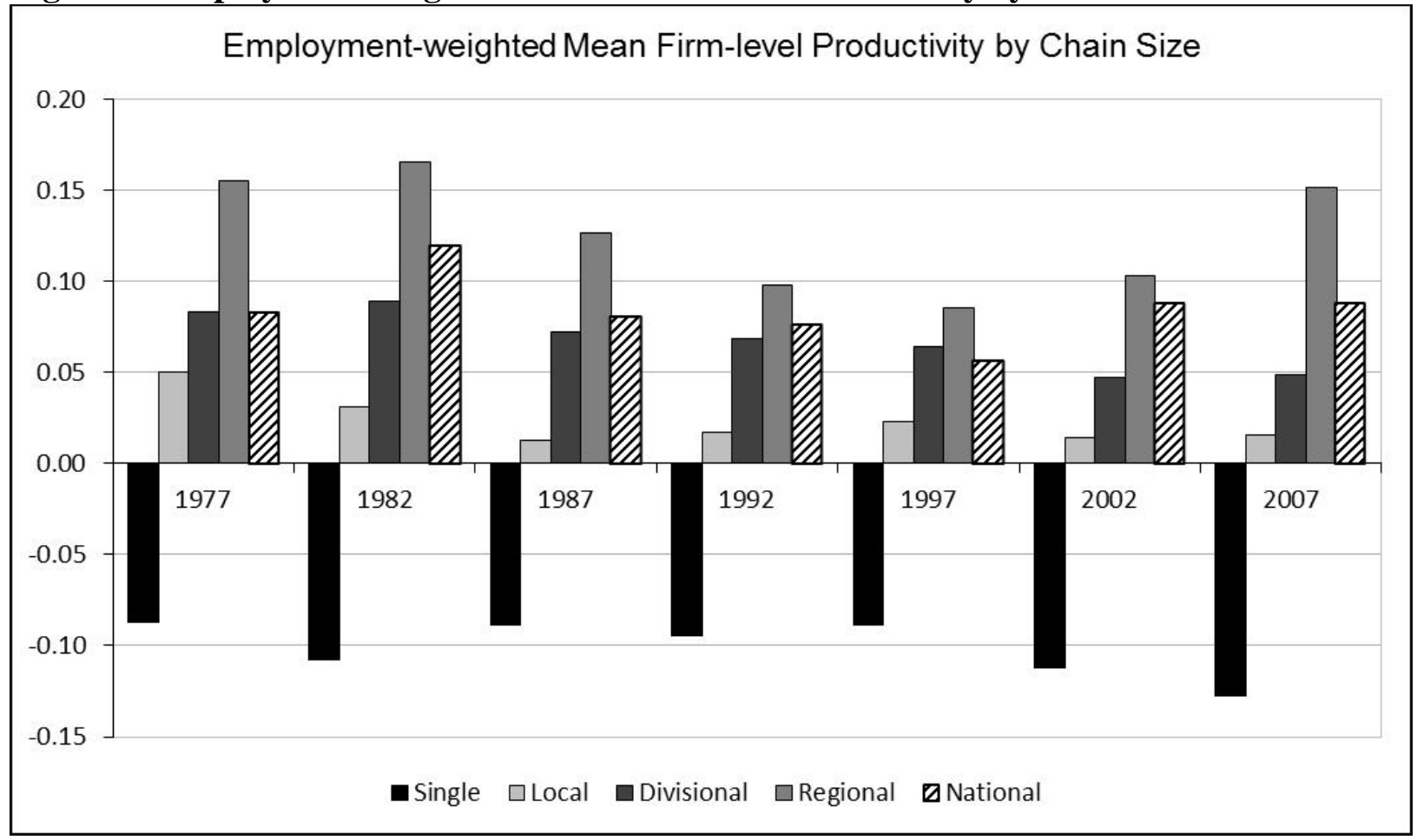


Figure 7: Share of National Chain Activity by Industry

\section{Employment}

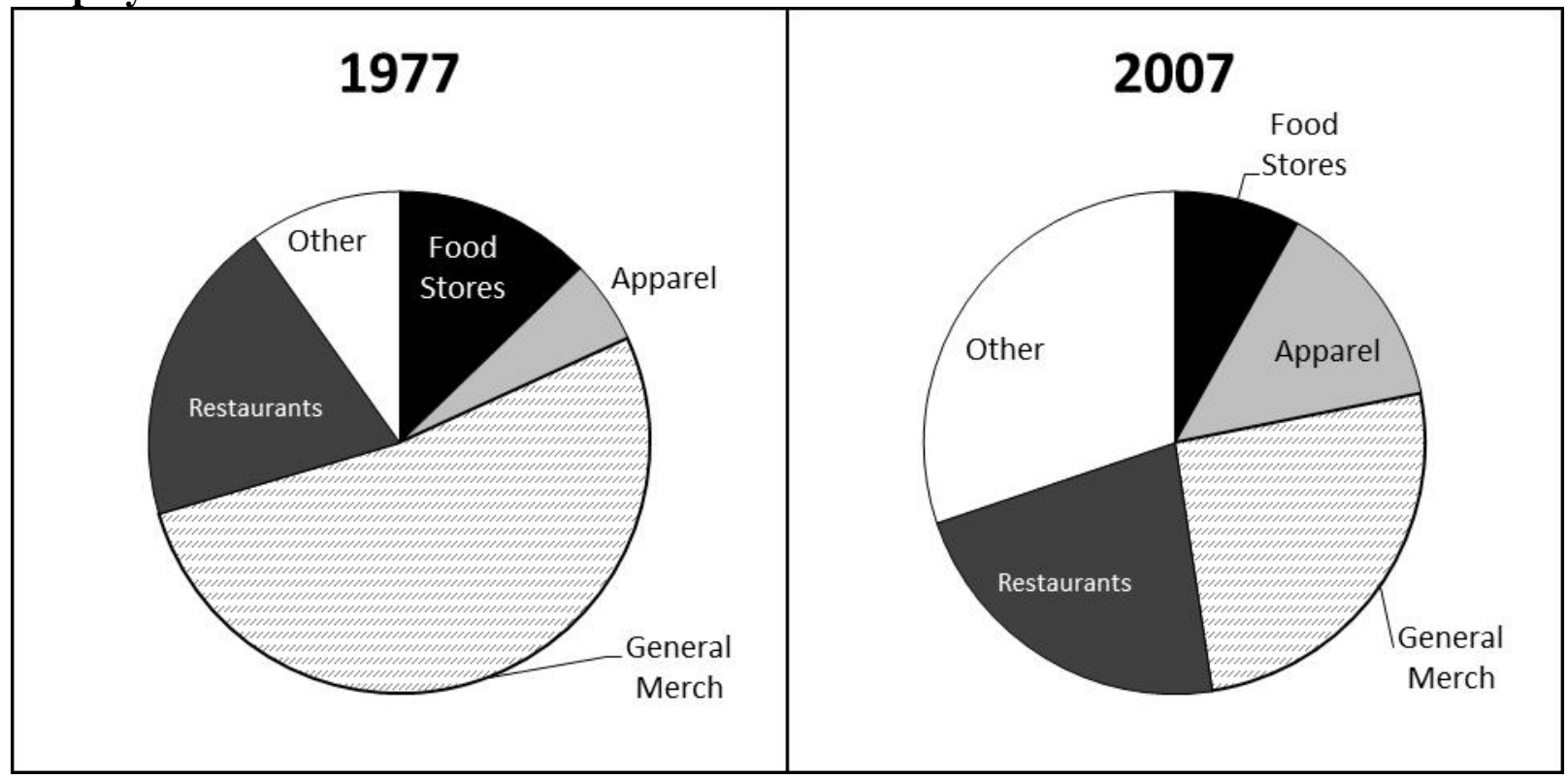

\section{Revenue}

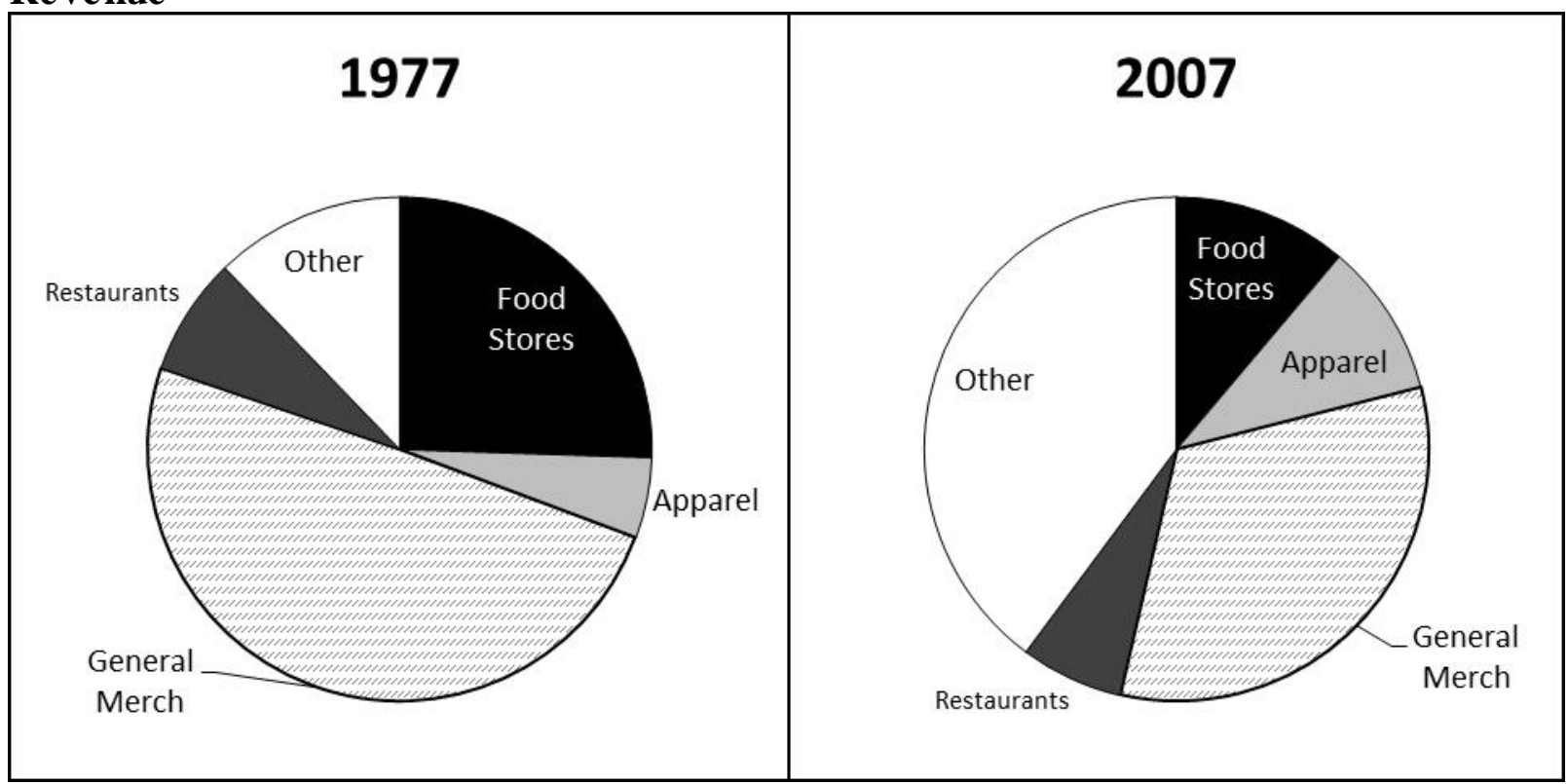

Note: 'Other' includes all 3-digit NAICS industries in the sample other than 'Food Stores', 'Apparel', 'General Merchandise', and 'Restaurants'. 
Figure 8: Selected Industries National Chain Activity

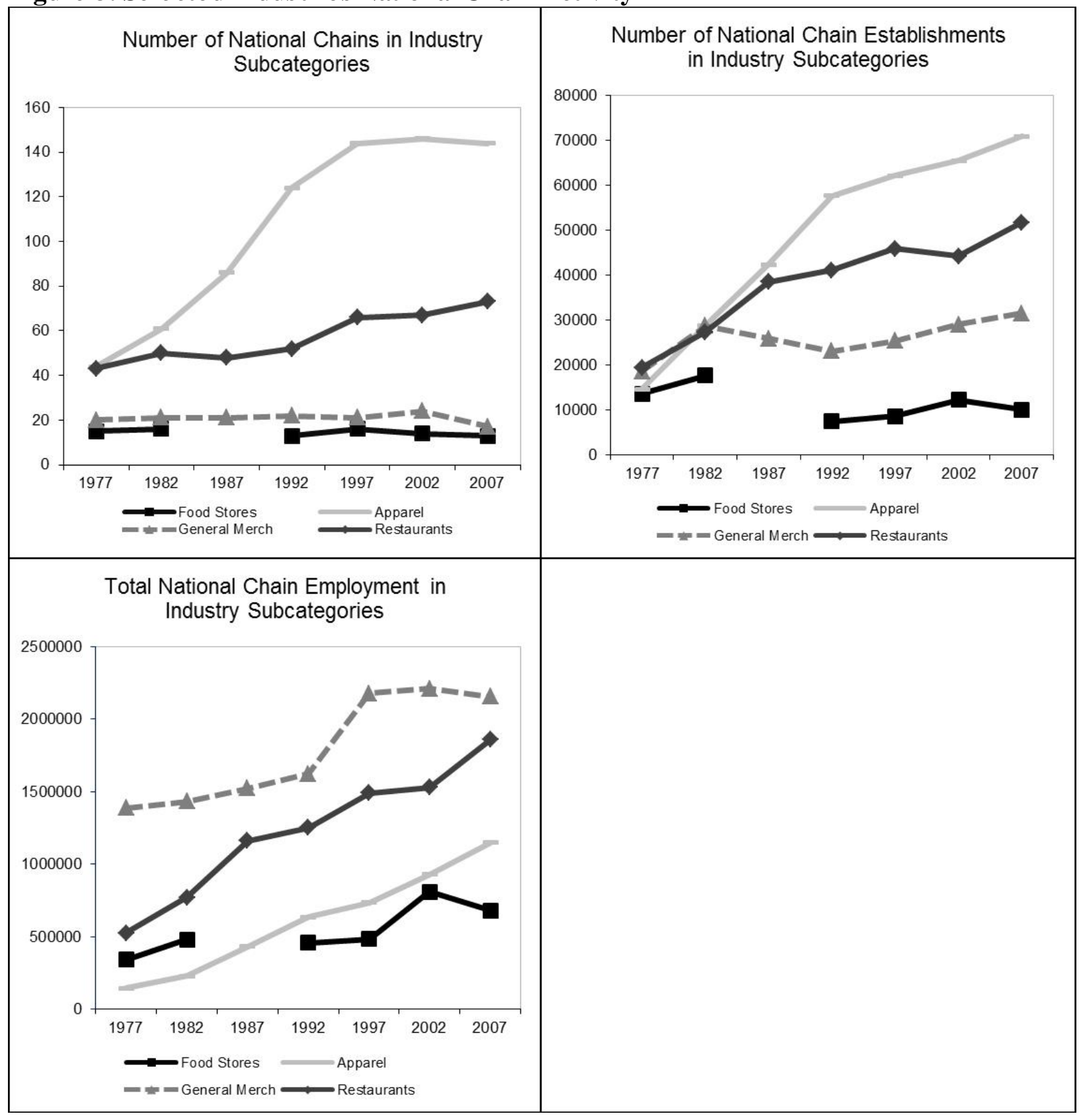


Figure 9: Selected Industries Prevalence of Chain Types (Employment)

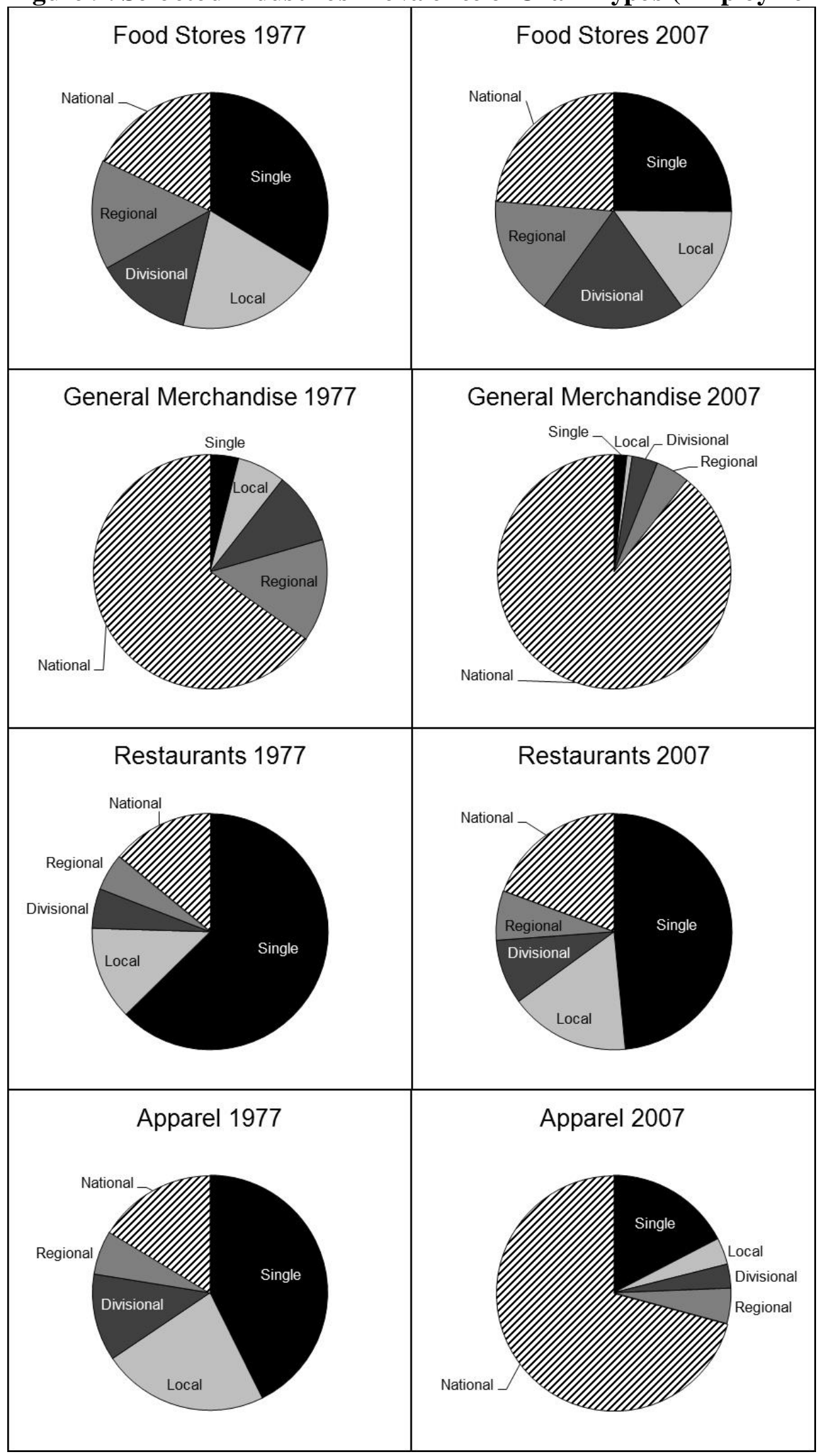


Figure 10: Selected Indus tries Within-State Saturation of National Chains

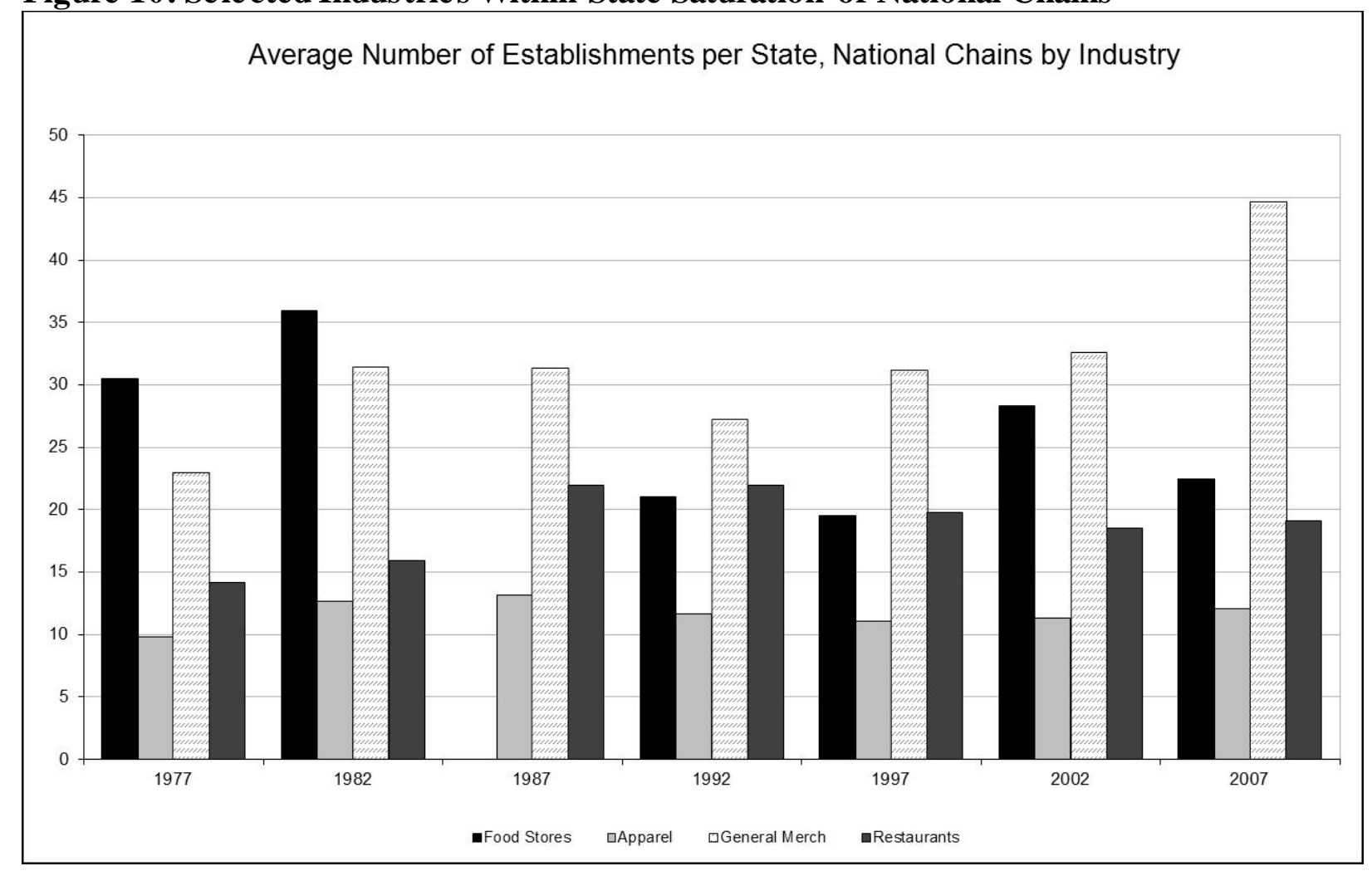


Figure 11: Selected Indus tries Evolution Path to National Chain in 2007

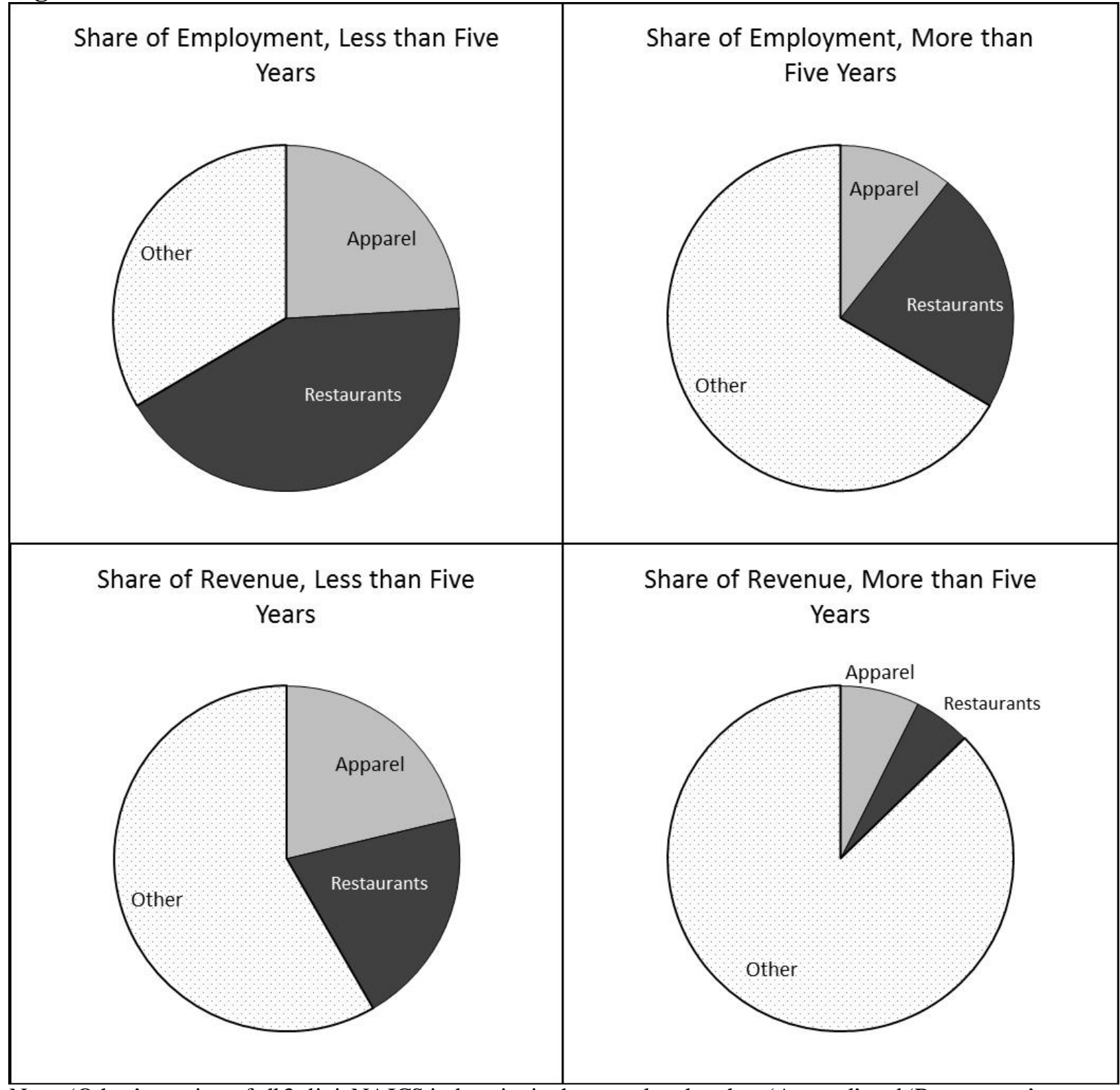

Note: 'Other' consists of all 3-digit NAICS indus tries in the sample other than 'Apparel' and 'Restaurants'. 